2017 Annual Reuse Report for the Idaho National Laboratory Site's Advanced Test Reactor Complex Cold Waste Ponds

February 2018

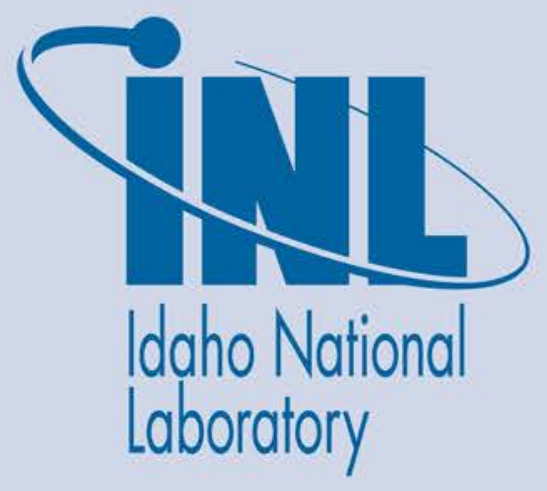

The INL is a U.S. Department of Energy National Laboratory operated by Battelle Energy Alliance 



\section{Annual Reuse Report for the Idaho National Laboratory Site's Advanced Test Reactor Complex Cold Waste Ponds}

February 2018

Idaho National Laboratory Idaho Falls, Idaho 83415

http://www.inl.gov

Prepared for the

U.S. Department of Energy

Office of Nuclear Energy, Science, and Technology

Under DOE Idaho Operations Office

Contract DE-AC07-05ID14517 


\section{ABSTRACT}

This report describes conditions and information, as required by the state of Idaho, Department of Environmental Quality Reuse Permit I-161-02, for the Advanced Test Reactor Complex Cold Waste Ponds located at Idaho National Laboratory from November 1, 2016-October 31, 2017. The effective date of Reuse Permit I-161-02 is November 20, 2014 with an expiration date of November 19, 2019. A permit modification, I-161-02: Modification 1, became effective March 7, 2017. The modification incorporated clarification to the delivery of analytical reports and chain of custody forms. This report contains the following information:

- Facility and system description

- $\quad$ Permit required effluent monitoring data and loading rates

- $\quad$ Permit required groundwater monitoring data

- $\quad$ Status of compliance activities

- $\quad$ Issues

- Discussion of the facility's environmental impacts.

During the 2017 permit year, 234.05 million gallons of wastewater were discharged to the Cold Waste Ponds which is below the maximum annual permit limit of 375 million gallons.

Sulfate and total dissolved solids concentrations continue to remain highest in well USGS-065, which is the closest downgradient well to the Cold Waste Ponds. As shown by the groundwater sampling data, sulfate and total dissolved solids concentrations decrease rapidly as the distance downgradient from the Cold Waste Ponds increases. The concentrations of all permit-required parameters were below their respective groundwater quality standard levels (IDAPA 58.01.11) for all six groundwater monitoring wells.

There was one noncompliance with the Reuse Permit during the 2017 permit year. Approximately 600 gallons of cooling water was discharged to ground surface outside of the designated application site. DEQ was notified of the noncompliance. 


\section{CONTENTS}

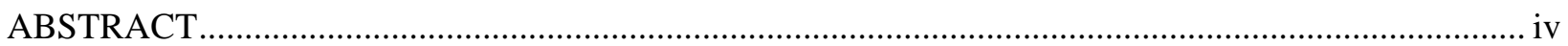

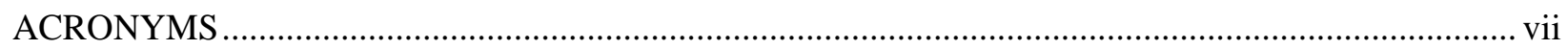

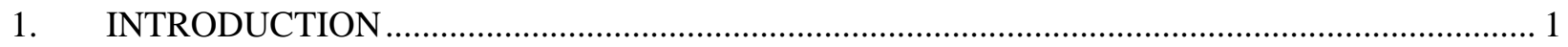

2. FACILITY, SYSTEM DESCRIPTION, AND OPERATION ….................................................... 1

3. COLD WASTE PONDS EFFLUENT MONITORING ............................................................. 4

3.1 Sampling Program and Analytical Methods ...................................................................... 4

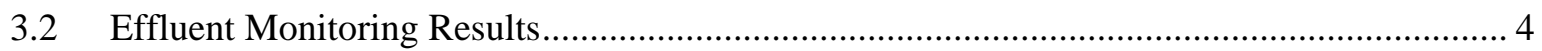

3.3 Flow Volumes and Hydraulic Loading Rates ................................................................. 7

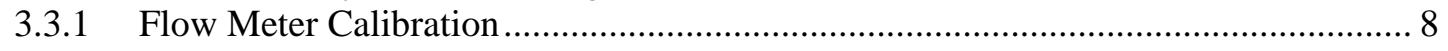

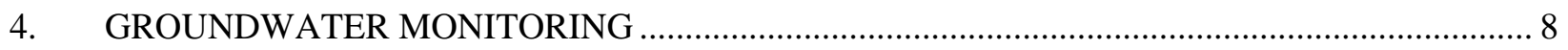

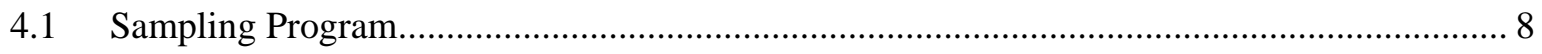

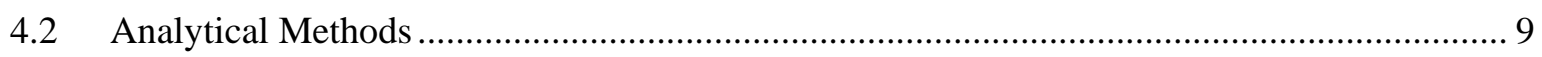

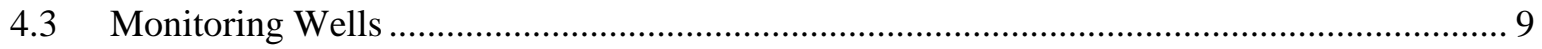

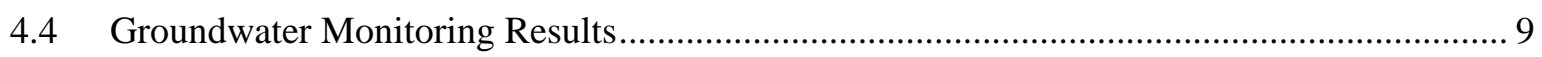

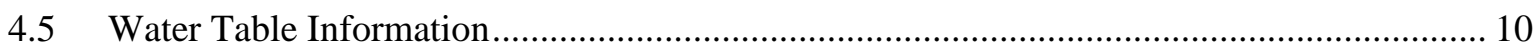

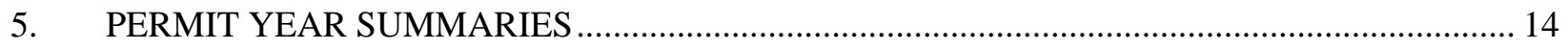

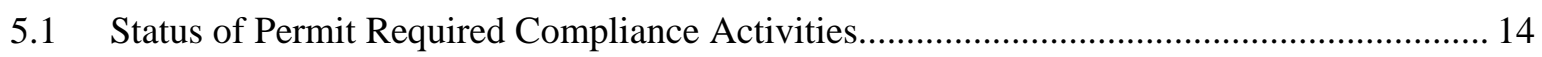

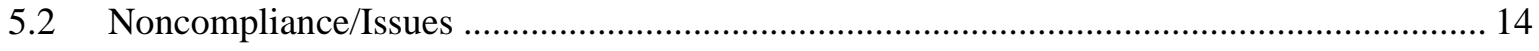

5.3 Department of Environmental Quality Annual Inspection ............................................... 15

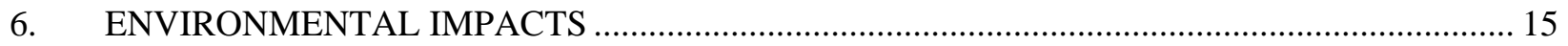

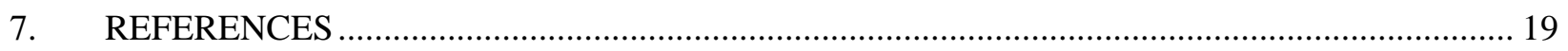

Appendix A Daily Discharge Volumes to the Advanced Test Reactor Complex Cold Waste Ponds 20

\section{FIGURES}

Figure 1. Advanced Test Reactor Complex facility map showing location of the Cold Waste Ponds, monitoring and drinking water wells, Big Lost River, and other associated

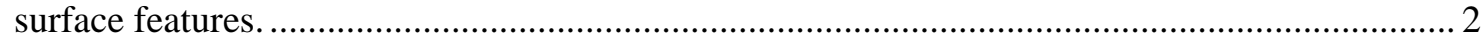

Figure 2. Advanced Test Reactor Complex Cold Waste system flow schematic....................................... 3

Figure 3. Advanced Test Reactor Complex Cold Waste Ponds wastewater 5-year moving average............ 8

Figure 4. Map showing depths and elevations based on the May 2017 water level measurements. .......... 12

Figure 5. Map showing depths and elevations based on the September 2017 water level measurements. 
Figure 7. Total dissolved solids concentrations in the Cold Waste Ponds monitoring wells.

\section{TABLES}

Table 1. Advanced Test Reactor Complex Cold Waste Ponds effluent (WW-16101) data for samples collected in accordance with Reuse Permit I-161-02 ................................................. 6

Table 2. Cold Waste Ponds flow summaries. .......................................................................................... 7

Table 3. Advanced Test Reactor Complex Cold Waste Ponds aquifer monitoring well data for the

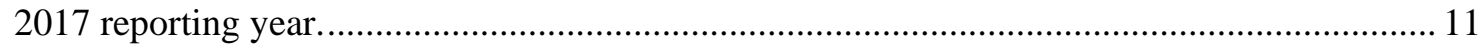

Table 4. Mann-Kendall trend analysis results for sulfate in the groundwater monitoring wells. ............... 17

Table 5. Mann-Kendall trend analysis results for total dissolved solids in the groundwater

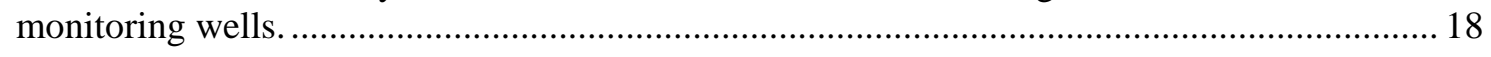

Table A-1. Daily discharge volumes to the ATR Complex CWP for the 2017 permit year...................... 22 


\section{ACRONYMS}

ATR Advanced Test Reactor

CCN correspondence control number

CFR Code of Federal Regulations

CTS Commitment Tracking System

CWP Cold Waste Pond(s)

DEQ Idaho Department of Environmental Quality

EPA U.S. Environmental Protection Agency

FM flow measurement or monitoring description or identifier

GW prefix for groundwater reporting serial number

IDAPA Idaho Administrative Procedures Act

INL Idaho National Laboratory

MDL method detection limit

MG million gallons

MU prefix for management unit reporting environmental serial number

NA Not Applicable

NAVD North American Vertical Datum

OOS out of service

PCS Primary Constituent Standard

PO Plan of Operation

QAPP Quality Assurance Project Plan

R\&MS Regulatory and Monitoring Services

SCS Secondary Constituent Standard

s.u. standard units for $\mathrm{pH}$

TDS total dissolved solids

TKN total Kjeldahl nitrogen

TN total nitrogen

TRA prefix for groundwater reporting (well) common designation number

USGS prefix for groundwater reporting (well) common designation number

WW prefix for wastewater reporting serial number 


\section{Annual Reuse Report for the Idaho National Laboratory Site's Advanced Test Reactor Complex Cold Waste Pondss}

\section{INTRODUCTION}

The Advanced Test Reactor (ATR) Complex Cold Waste Ponds (CWP) is a reuse facility operated by Battelle Energy Alliance, LLC at Idaho National Laboratory (INL). During the 2017 reporting year, operations were conducted under Reuse Permit No. I-161-02 (Neher 2014) and Reuse Permit No. I-16102, Modification 1, which became effective March 7, 2017 (Neher 2017) as issued by the State of Idaho Department of Environmental Quality (DEQ). The modification incorporated clarification to the delivery of analytical reports and chain of custody forms. The permit expires on November 19, 2019.

This annual report summarizes the facility system and operation, monitoring data, special compliance conditions, issues/noncompliances, and environmental impacts for the 2017 reporting year (November 1, 2016, through October 31, 2017).

\section{FACILITY, SYSTEM DESCRIPTION, AND OPERATION}

The ATR Complex (Figure 1) is located on approximately 100 acres in the southwestern portion of INL, approximately 47 miles west of Idaho Falls, Idaho, in Butte County. The ATR Complex consists of buildings and structures utilized to conduct research associated with developing, testing, and analyzing materials used in nuclear and reactor applications and both radiological and nonradiological laboratory analyses.

The CWP are located approximately $450 \mathrm{ft}$ from the southeast corner of the ATR Complex compound and approximately 3/4 of a mile northwest of the Big Lost River channel (Figure 1). The existing CWP were excavated in 1982. The CWP consist of two cells, each with dimensions of $180 \times 430 \mathrm{ft}$ across the top of the berms, and a depth of $10 \mathrm{ft}$. Total surface area for the two cells at the top of the berms is approximately 3.55 acres. Maximum capacity is approximately 10,220,000 gal (31.3 acre ft).

Wastewater discharged to the CWP consists primarily of noncontact cooling tower blowdown, once-through cooling water for air conditioning units, coolant water from air compressors, secondary system drains, and other nonradioactive drains throughout the ATR Complex. The wastewater flows through collection piping to the TRA-764 Cold Waste Sample Pit (Figure 2) where the flow rate is recorded and compliance monitoring samples are collected. The wastewater then flows to the Cold Waste Sump Pit (TRA-703). The sump pit contains submersible pumps that route the water to the appropriate pond through 8-in. valves.

Wastewater enters the ponds through concrete inlet basins located near the west end. Most of the water percolates into the porous ground within a short distance from the inlet basins. The entire floor of a pond is rarely submerged. If the water level rises significantly in a pond (e.g., $5 \mathrm{ft}$ ), the flow would be diverted to the adjacent pond, allowing the first pond to dry out. An overflow pipe connects the two ponds at the 9-ft level.

The normal operation is to route the wastewater to one pond at a time. Historically, the flow to the ponds was switched annually. Section 4.2 of the Reuse Permit states "DEQ recommends each basin be operated using periods of wetting and drying cycles at set frequencies that provide for both anaerobic and aerobic treatment of the wastewater through the vadose zone.”

Beginning in February 2015, the frequency for switching ponds was increased to approximately monthly. The dates when the effluent flow to the ponds were switched can be found in Appendix A. The change in frequency is based on a modeled vadose zone drain-out period for the zone above the shallow perched water zone below the CWP. 
There are no existing or planned cross-connections or interconnections between the Cold Waste System wastewater and any water supplies (potable or nonpotable) that would require backflow prevention devices or methods.

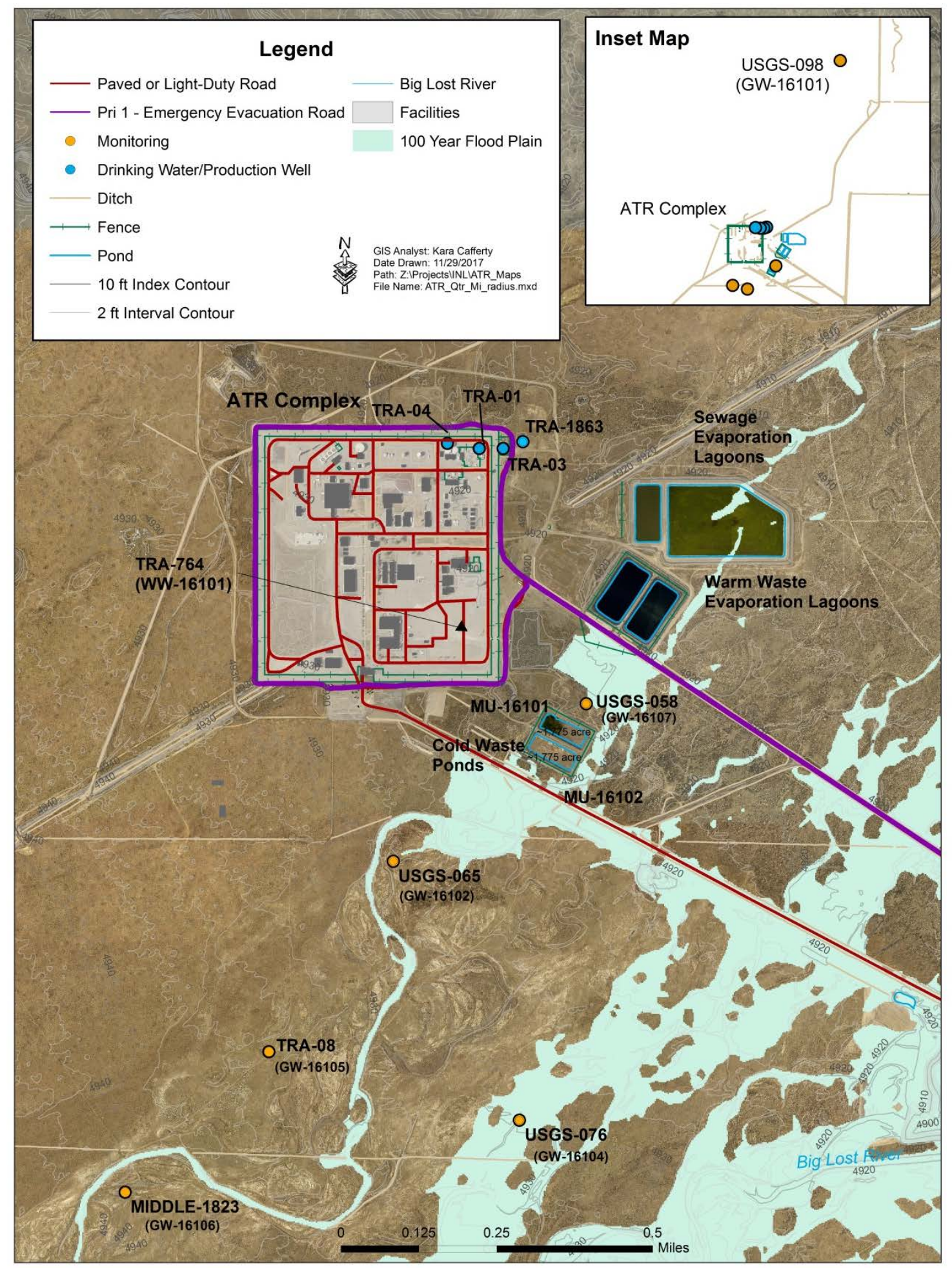

Figure 1. Advanced Test Reactor Complex facility map showing location of the Cold Waste Ponds, monitoring and drinking water wells, Big Lost River, and other associated surface features. 


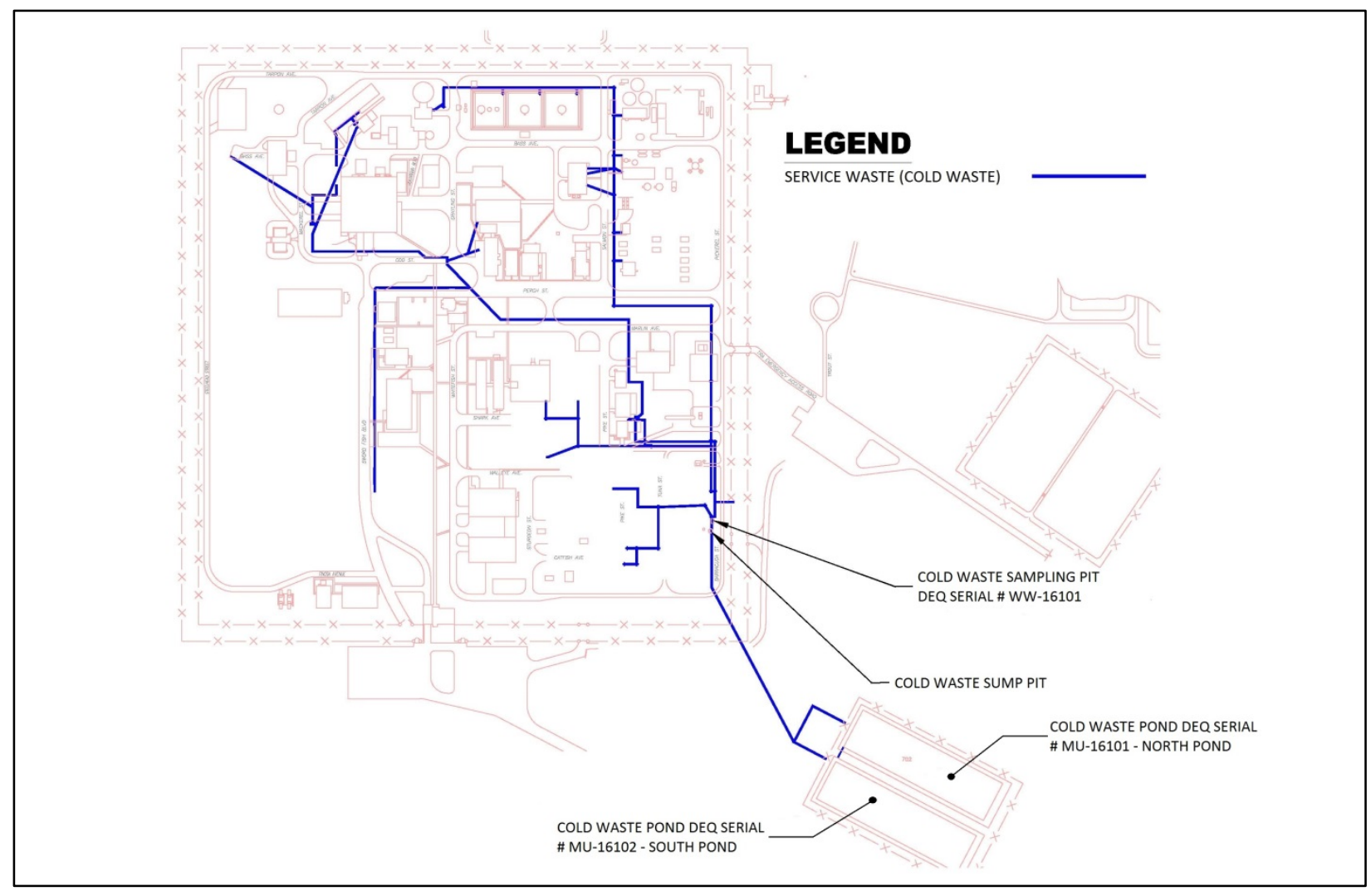

Figure 2. Advanced Test Reactor Complex Cold Waste system flow schematic. 


\section{COLD WASTE PONDS EFFLUENT MONITORING}

This section describes the sampling and analytical methods used in the ATR Complex CWP effluent monitoring program. Effluent monitoring and flow data for wastewater discharged to the ATR Complex CWP are provided.

\subsection{Sampling Program and Analytical Methods}

Battelle Energy Alliance, LLC, Regulatory and Monitoring Services (R\&MS) personnel monitor effluent discharges at the ATR Complex CWP. The R\&MS program involves sampling, analysis, and data interpretation carried out under a quality assurance program. A Quality Assurance Project Plan (QAPP), as required by the Reuse Permit, was submitted to DEQ on May 18, 2015 (Miller 2015a).

The QAPP identifies the scope of monitoring, the organization and individuals involved, data quality objectives, monitoring procedures, and specific quality control measures. The purpose of the QAPP is to ensure data of sufficient quantity and quality are collected to meet permit and regulatory expectations.

Regulatory and Monitoring Services personnel collect monthly effluent samples as required in Section 5.1.1 of the Reuse Permit. Effluent samples were collected from the TRA-764 Cold Waste Sample Pit (sampling location WW-16101) prior to discharge to the CWP. All samples were collected according to established programmatic sampling procedures. These procedures are now identified in the QAPP.

Effluent sampling events are randomly scheduled within the constraints of the sampling staff and laboratory availability. Effluent samples are typically collected early in the month (first or second week) and on a Tuesday or Wednesday of the selected week. This ensures the laboratory can receive the samples during normal working hours so that temperature control and holding time requirements are met. This also allows time in the month to collect samples in the event there are issues with the original samples, sampling equipment, flow meter, etc. On occasion, the sampling schedule must be changed, but the rescheduled events always occur within the same month as the original scheduled event.

Analytical methods specified in 40 Code of Federal Regulations (CFR) 141, "National Primary Drinking Water Regulations”; 40 CFR 143, "National Secondary Drinking Water Regulations,” or 40 CFR 136, "Guidelines Establishing Test Procedures for the Analysis of Pollutants” were used for analysis of all permit-required parameters.

Permit required effluent $\mathrm{pH}$ and conductivity analyses are performed at the time of sample collection by R\&MS personnel using a calibrated meter. All other permit required samples were submitted under full chain of custody to GEL Laboratories in Charleston, South Carolina.

\subsection{Effluent Monitoring Results}

Effluent samples were collected monthly from the TRA-764 Cold Waste Sample Pit (prior to discharge to the CWP) during the permit year. Effluent samples were collected as 24-hour flow proportional composite samples. All samples were collected and analyzed as required by the permit (Table 1). The permit year covered in this report is November 1, 2016-October 31, 2017.

Total nitrogen is a permit required parameter and there are no permit limits for total nitrogen. Total nitrogen is calculated as the sum of total Kjeldahl nitrogen (TKN) and nitrate plus nitrite nitrogen. For results reported as a negative value, the method detection limit (MDL) of $0.033 \mathrm{mg} / \mathrm{L}$ replaced the result for calculation purposes and the product was reported as a less than $(<)$ number. For positive results reported below the instrument detection limit, the MDL was used in the total nitrogen calculation and the product was also reported as a less than $(<)$. Total nitrogen concentrations in the effluent ranged between $<0.90 \mathrm{mg} / \mathrm{L}$ in the August 2017 sample to $4.87 \mathrm{mg} / \mathrm{L}$ in the June 2017 sample (Table 1). 
Although, there are no effluent permit limits for total dissolved solids (TDS) or sulfate, these parameters are roughly $100 \mathrm{mg} / \mathrm{L}$ higher in USGS-065 than the other five groundwater monitoring wells evaluated for this permit. Therefore, a summary comparison of these parameters with the Ground Water Quality Rule Secondary Constituent Standards (SCS) found in Idaho Administrative Procedures Act (IDAPA) 58.01.11.200.01.b. is provided below:

The SCS for TDS is $500 \mathrm{mg} / \mathrm{L}$. The TDS concentration in the effluent to the CWP ranged from 223 $\mathrm{mg} / \mathrm{L}$ in the July and September 2017 samples to 1,220 mg/L in the June 2017 sample (Table 1). Concentrations of TDS in the effluent were above the SCS level in 4 out of the 12 months.

Similar to the TDS effluent levels, sulfate concentrations were above the SCS of $250 \mathrm{mg} / \mathrm{L}$ in 4 of the 12 monthly samples (Table 1). Sulfate ranged from a minimum of $20.2 \mathrm{mg} / \mathrm{L}$ in the July 2017 sample to a maximum of $644 \mathrm{mg} / \mathrm{L}$ in the June 2017 sample.

The ATR evaporative cooling process evaporates approximately one-half of the water volume and concentrates naturally occurring TDS and additives in the blowdown discharged to the CWP. Elevated sulfate levels are generated by reactions between sulfuric acid additives placed in the cooling water and calcium and magnesium carbonates in the water.

Total iron concentrations ranged from less than $0.033 \mathrm{mg} / \mathrm{L}$, in multiple samples, to $0.288 \mathrm{mg} / \mathrm{L}$, in the sample collected November 2016. For comparison, the filtered (dissolved) iron concentrations ranged from less than $0.033 \mathrm{mg} / \mathrm{L}$, in half the samples, to $0.269 \mathrm{mg} / \mathrm{L}$. The remaining metal concentrations remained at low levels.

Several effluent sample results were qualified during data validation. Although the reported concentrations may be considered questionable, inaccurate, or imprecise, the estimated values are provided in Table 1. These qualified data are discussed below:

- The July 6, 2017, nitrite + nitrate sample and field duplicate sample results were J qualified due to high matrix spike recovery and poor replicate precision.

- The TKN result for the sample collected February 7, 2017, was J qualified due to high initial calibration bias and low matrix spike recovery.

- The TKN results for the samples collected March 8, 2017, and May 10, 2017, were U qualified both due to blank contamination. A qualification of $U$ during data validation indicates the analyte was detected at or above the applicable detection limit but the value was not more than 5 times the highest positive amount in any laboratory blank.

- $\quad$ The TKN result for the samples collected April 12, 2017; July 6, 2017; August 9, 2017; and October 5, 2017, were UJ qualified due to blank contamination and low matrix spike recoveries.

- $\quad$ The chloride results for the samples collected January 17, 2017; February 7, 2017; April 12, 2017; August 9, 2017; and October 5, 2017, were J qualified due to high initial calibration and high initial calibration biases.

- The sulfate results for the samples collected April 12, 2017, and June 6, 2017, were J qualified due to high calibration verification bias and high matrix spike recovery.

- The manganese results for samples collected February 7, 2017, and June 6, 2017, were J qualified due to the potential for a false positive and a high initial calibration. 
Table 1. Advanced Test Reactor Complex Cold Waste Ponds effluent (WW-16101) data for samples collected in accordance with Reuse Permit I$161-02$.

\begin{tabular}{|c|c|c|c|c|c|c|c|c|c|c|c|c|}
\hline Sample Month & November & December & January & February & March & April & May & June & July $^{\mathrm{a}}$ & August & September & October \\
\hline Sample Date & $11 / 03 / 16$ & $12 / 08 / 16$ & $1 / 17 / 2017$ & 2/7/2017 & $3 / 8 / 2017$ & $4 / 12 / 2017$ & $5 / 10 / 2017$ & 6/6/2017 & $7 / 6 / 2017$ & $08 / 9 / 17$ & 09/14/17 & $10 / 05 / 17$ \\
\hline $\begin{array}{c}\text { Nitrite + nitrate as nitrogen } \\
(\mathrm{mg} / \mathrm{L})\end{array}$ & 3.59 & 0.912 & 2.77 & 2.88 & 1.02 & 0.941 & 0.885 & 3.68 & $\begin{array}{c}1.14 \mathrm{~J}^{\mathrm{b}} \\
(1.05) \mathrm{J}\end{array}$ & 0.87 & 0.905 & 0.935 \\
\hline $\begin{array}{c}\text { Total Kjeldahl nitrogen } \\
(\mathrm{mg} / \mathrm{L})\end{array}$ & 0.772 & $0.0214 \mathrm{U}^{\mathrm{c}}$ & 0.864 & $0.818 \mathrm{~J}$ & $0.0957 \mathrm{U}$ & $0.0907 \mathrm{UJ}^{\mathrm{d}}$ & $0.0613 \mathrm{U}$ & 1.19 & $\begin{array}{l}0.00198 \mathrm{UJ} \\
(0.181 \mathrm{UJ})\end{array}$ & $-0.014 \mathrm{UJ}$ & $-0.0209 U$ & $0.129 \mathrm{UJ}$ \\
\hline Total nitrogen $^{\mathrm{e}}(\mathrm{mg} / \mathrm{L})$ & 4.36 & 0.93 & 3.63 & 3.70 & 1.12 & 1.03 & 0.95 & 4.87 & $1.14(1.23)$ & $<0.90$ & $<0.94$ & 1.06 \\
\hline $\mathrm{pH}$ (s.u.) & 6.94 & 7.19 & 6.80 & 6.64 & 7.17 & 7.50 & 7.36 & 6.59 & 6.70 & 6.90 & 7.18 & 7.45 \\
\hline $\begin{array}{l}\text { Electrical conductivity } \\
(\mu \mathrm{S} / \mathrm{cm})\end{array}$ & 1,438 & 481 & 1,173 & 1,200 & 458 & 397 & 444 & 1,324 & 452 & 479 & 435 & 447 \\
\hline Chloride (mg/L) & 42.1 & 9.75 & $37.7 \mathrm{~J}$ & $35 \mathrm{~J}$ & 11.7 & $12.9 \mathrm{~J}$ & 11.4 & 44.5 & $9.20(9.24)$ & $9.88 \mathrm{~J}$ & 11.9 & $13.2 \mathrm{~J}$ \\
\hline Sulfate $(\mathrm{mg} / \mathrm{L})$ & 616 & 22.2 & 432 & 465 & 46.5 & $28.5 \mathrm{~J}$ & 27.0 & $644 \mathrm{~J}$ & $20.2(20.2)$ & 21.3 & 27.4 & 34.7 \\
\hline Total dissolved solids (mg/L) & 1,130 & 256 & 880 & 904 & 269 & 224 & 231 & 1,220 & $223(227)$ & 239 & 223 & 231 \\
\hline Aluminum, total (mg/L) & 0.0438 & 0.0222 & 0.0412 & $0.015 \mathrm{U}$ & 0.0165 & $0.0193 \mathrm{U}$ & $0.0193 \mathrm{U}$ & 0.0208 & $\begin{array}{l}0.0193 \mathrm{U} \\
(0.0285) \\
\end{array}$ & $0.0193 \mathrm{U}$ & $0.0193 \mathrm{U}$ & $0.0193 \mathrm{U}$ \\
\hline Aluminum, filtered (mg/L) & 0.0379 & 0.016 & 0.034 & $0.015 \mathrm{U}$ & $0.015 \mathrm{U}$ & $0.0193 \mathrm{U}$ & $0.0193 \mathrm{U}$ & $0.0193 \mathrm{U}$ & $\begin{array}{c}0.0193 \mathrm{U} \\
(0.028) \\
\end{array}$ & $0.0193 \mathrm{U}$ & $0.0193 \mathrm{U}$ & $0.0193 \mathrm{U}$ \\
\hline Chromium, total (mg/L) & 0.0144 & 0.00375 & 0.00957 & 0.0102 & 0.00353 & 0.00455 & 0.00374 & 0.0158 & $\begin{array}{c}0.00484 \\
(0.00508) \\
\end{array}$ & 0.00432 & 0.00441 & 0.00419 \\
\hline Chromium, filtered (mg/L) & 0.0149 & 0.00382 & 0.00971 & 0.0105 & 0.00335 & 0.0041 & 0.00355 & 0.0152 & $\begin{array}{c}0.00495 \\
(0.047) \\
\end{array}$ & 0.00456 & 0.00449 & 0.00451 \\
\hline Iron, total $(\mathrm{mg} / \mathrm{L})$ & 0.288 & $0.033 \mathrm{U}$ & 0.209 & 0.0338 & $0.033 \mathrm{U}$ & $0.033 \mathrm{U}$ & $0.033 \mathrm{U}$ & 0.070 & $\begin{array}{c}0.065 \\
(0.0527) \\
\end{array}$ & 0.0971 & 0.124 & 0.139 \\
\hline Iron, filtered (mg/L) & 0.269 & $0.033 \mathrm{U}$ & 0.189 & $0.033 \mathrm{U}$ & $0.033 \mathrm{U}$ & $0.033 \mathrm{U}$ & $0.033 \mathrm{U}$ & $0.033 \mathrm{U}$ & $\begin{array}{c}0.0452 \\
(0.0439) \\
\end{array}$ & 0.0957 & 0.121 & 0.108 \\
\hline Manganese, total (mg/L) & 0.00242 & $0.001 \mathrm{U}$ & $0.001 \mathrm{U}$ & $0.00112 \mathrm{~J}$ & $0.001 \mathrm{U}$ & $0.001 \mathrm{U}$ & $0.001 \mathrm{U}$ & $0.00375 \mathrm{~J}$ & $\begin{array}{c}0.001 \mathrm{U} \\
(0.001 \mathrm{U})\end{array}$ & $0.001 \mathrm{U}$ & $0.001 \mathrm{U}$ & 0.00198 \\
\hline Manganese, filtered (mg/L) & 0.00235 & $0.001 \mathrm{U}$ & $0.001 \mathrm{U}$ & $0.00106 \mathrm{~J}$ & $0.001 \mathrm{U}$ & $0.001 \mathrm{U}$ & $0.001 \mathrm{U}$ & $0.00348 \mathrm{~J}$ & $\begin{array}{c}0.001 \mathrm{U} \\
(0.001 \mathrm{U})\end{array}$ & $0.001 \mathrm{U}$ & $0.001 \mathrm{U}$ & 0.00127 \\
\hline \multicolumn{13}{|c|}{$\begin{array}{l}\text { a. Results shown in parenthesis are from field duplicate samples collected in July. } \\
\text { b. J flag indicates the associated value is an estimate and may be inaccurate or imprecise. } \\
\text { c. U qualification indicates the analyte was not detected above the instrument detection limit or the analyte was detected at or above the applicable detection limit but the value is not more than } 5 \text { times the } \\
\text { highest positive amount in any laboratory blank and is U qualified as a result of data validation. } \\
\text { d. UJ flag indicates the sample was analyzed for, but was not detected. The associated value is an estimate and may be inaccurate or imprecise. } \\
\text { e. Total nitrogen is calculated as the sum of the TKN, nitrite nitrogen, and nitrate nitrogen. For results reported as a negative value, the method detection limit (MDL) of } 0.033 \mathrm{mg} / \mathrm{L} \text { replaced the result for } \\
\text { calculation purpose and the product was reported as a less than }(<) \text { number. For positive results reported below the instrument detection limit, the MDL was used in the total nitrogen calculation and the } \\
\text { product was reported as a less than }(<) \text {. Results were rounded to the nearest hundredth. }\end{array}$} \\
\hline
\end{tabular}




\subsection{Flow Volumes and Hydraulic Loading Rates}

Daily flow readings were taken by ATR Complex CWP Operations during the 2017 permit year, as required by Section 5.1.2 of the Reuse Permit, at the TRA-764 Cold Waste Sample Pit where the flow meter (FM-16101) is located. The flow meter measures flow to the North Pond (MU-16101) and to the South Pond (MU-16102). All flow readings were recorded in gallons per day.

Table 2 summarizes monthly and annual flow data. Daily effluent flow data is provided in Appendix A.

Table 2. Cold Waste Ponds flow summaries.

\begin{tabular}{|c|c|c|c|}
\hline Month & $\begin{array}{c}\text { North Pond } \\
\text { (MU-16101) } \\
\text { (MG) }^{\mathrm{a}} \\
\end{array}$ & $\begin{array}{c}\text { South Pond } \\
\text { (MU-16102) } \\
\text { (MG) }\end{array}$ & $\begin{array}{c}\text { Monthly Total for } \\
\text { Both Ponds } \\
\text { (MG) } \\
\end{array}$ \\
\hline November 2016 & 17.00 & 0.00 & 17.00 \\
\hline December 2016 & 0.76 & 16.79 & 17.55 \\
\hline January 2017 & 12.61 & 0.39 & 13.00 \\
\hline February 2017 & 0.00 & 12.27 & 12.27 \\
\hline March 2017 & 23.24 & 0.00 & 23.24 \\
\hline April 2017 & 1.40 & 21.46 & 22.86 \\
\hline May 2017 & 22.55 & 0.00 & 22.55 \\
\hline June 2017 & 0.00 & 20.28 & 20.28 \\
\hline July 2017 & 23.80 & 0.90 & 24.70 \\
\hline August 2017 & 0.00 & 24.10 & 24.10 \\
\hline September 2017 & 20.33 & 3.22 & 23.55 \\
\hline October 2017 & 0.00 & 12.95 & 12.95 \\
\hline Annual Total & 121.69 & 112.36 & 234.05 \\
\hline
\end{tabular}

Section 4.2 of the permit requires that the total annual volume discharged to the North and South Ponds shall not exceed a 5-year moving annual average of 300 million gallons (MG)/year. No single year shall exceed $375 \mathrm{MG} / \mathrm{yr}$. Annual hydraulic loading data from previous reporting years are used to determine compliance with the moving annual average. Figure 3 shows that the 5-year moving average is below the permit limit. 


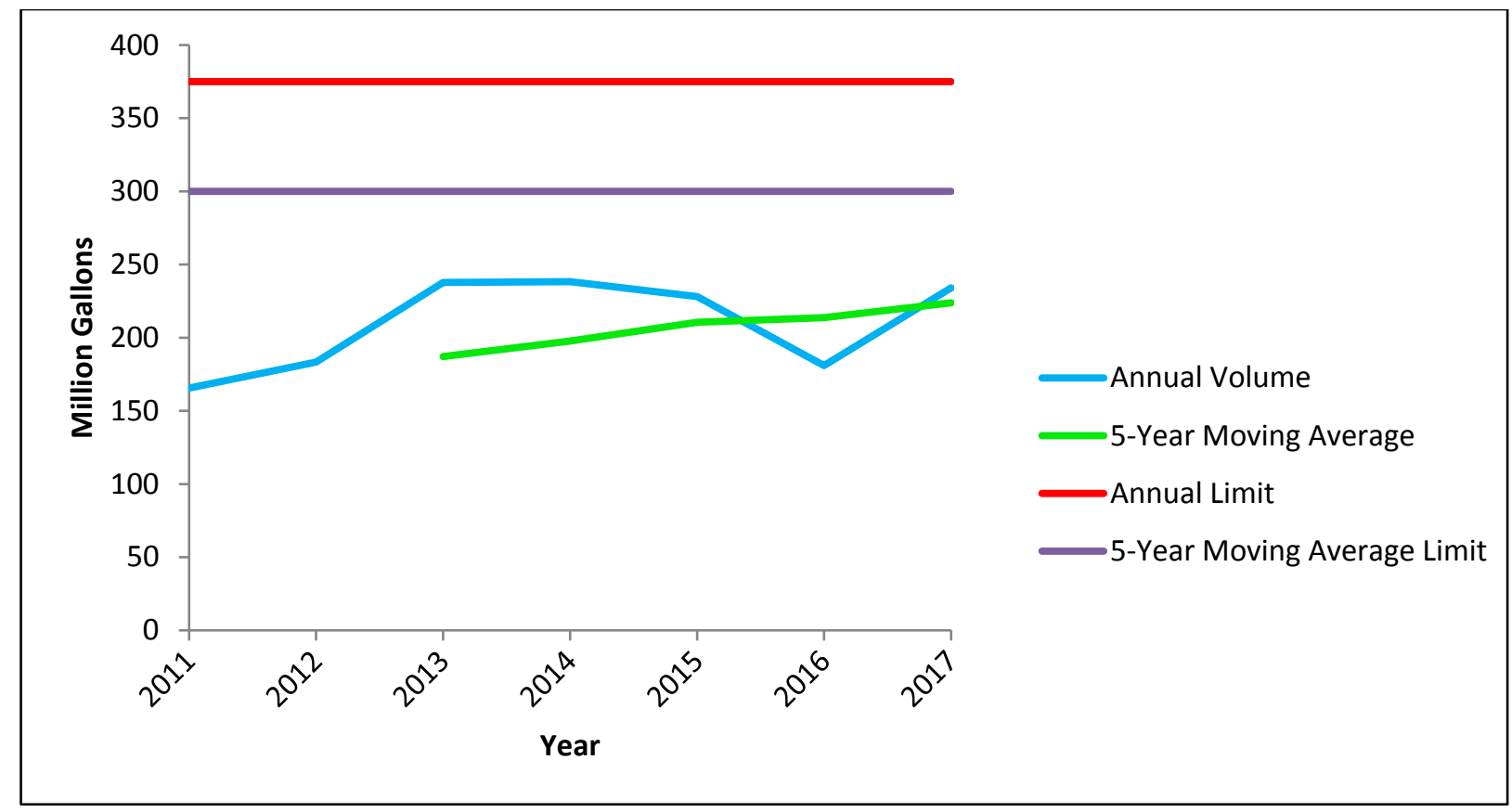

Figure 3. Advanced Test Reactor Complex Cold Waste Ponds wastewater 5-year moving average.

For permit year 2017, the total volume discharged to the North and South ponds was 121.69 MG and 112.36 MG, respectively. The total annual volume discharged to both ponds was 234.05 MG which is significantly less than the maximum Reuse Permit annual limit of 375 MG.

\subsubsection{Flow Meter Calibration}

Calibration is performed annually and was performed on June 8, 2017, by the ATR Complex maintenance organization. The calibrations were performed to $+/-2 \%$ of full scale (full scale $=1400$ gpm). The as found calibration of the flow meter was determined to be satisfactory.

\section{GROUNDWATER MONITORING}

The groundwater monitoring sections provide information concerning the INL sampling program, analytical methods used, and monitoring results, and water table information.

\subsection{Sampling Program}

The ATR Complex CWP Reuse Permit identifies six INL compliance wells. The permit requires that groundwater samples be collected from these six compliance wells semiannually in April or May and September or October.

The R\&MS personnel collected groundwater samples in May and September 2017. The R\&MS personnel use project-specific sampling and analysis plans and procedures that govern sampling activities and quality control protocols. The 2017 groundwater sampling was conducted in accordance with the QAPP that was submitted to DEQ on May 18, 2015 (Miller 2015a). The permit identifies a specific list of parameters that are to be analyzed in the groundwater samples. Constituent concentrations in the compliance wells are limited by primary constituent standards (PCS) and SCS specified in IDAPA 58.01.11, "Ground Water Quality Rule” with the exception of chromium. In accordance with the Reuse Permit, Section 5.2.2, footnote a., "compliance with the Primary Constituent Standard for Chromium, under this permit, shall not apply." 
As required by the Reuse Permit, unfiltered samples were collected and analyzed for nitrate + nitrite, as nitrogen, TKN, TDS, pH, electrical conductivity, chloride, chromium, and sulfate. Filtered samples were collected and analyzed for aluminum, chromium, iron, and manganese.

Groundwater $\mathrm{pH}$ and conductivity analyses are performed at the time of sample collection by R\&MS personnel using a calibrated meter(s). All other permit required groundwater samples are submitted under full chain of custody to GEL Laboratories in Charleston, South Carolina for analysis.

\subsection{Analytical Methods}

Analytical methods specified in 40 CFR 141, "National Primary Drinking Water Regulations”; 40 CFR 143, "National Secondary Drinking Water Regulations” or 40 CFR 136, "Guidelines Establishing Test Procedures for the Analysis of Pollutants" were used for analysis of all permit-required parameters.

\subsection{Monitoring Wells}

To measure potential impacts to groundwater from the ATR Complex CWP, the permit requires that groundwater samples be collected from six monitoring wells located in the Snake River Plain Aquifer (Figure 1):

- USGS-098 (GW-16101)

- USGS-065 (GW-16102)

- USGS-076 (GW-16104)

- TRA-08 (GW-16105)

- Middle-1823 (GW-16106)

- USGS-058 (GW-16107).

All six wells are Reuse Permit compliance points. Wells with sufficient water volume are purged to a minimum of three casing volumes or one well volume with three successive field measurements, taken not less than one minute apart, for $\mathrm{pH}$, conductivity, and temperature and meet the following conditions: temperature must be within $1^{\circ} \mathrm{C}$ of each other, and conductivity values must be within $10 \%$ of each other (LI-330).

Groundwater monitoring well TRA-07 (GW-16103) was required under the previous permit as a compliance point monitoring well. However, under the current Reuse Permit Section 5.2.1 "Ground Water Monitoring Point Descriptions" table references TRA-07 in the table's footnotes as "not required under this permit.” Therefore, no samples or water level information were obtained from this well.

\subsection{Groundwater Monitoring Results}

Table 3 shows the 2017 reporting year water table elevations and depth to water table, determined prior to purging and sampling, and the analytical results for all parameters specified by the permit for the six aquifer wells. For USGS-058, the Reuse Permit only requires sampling, analysis, and reporting of TDS and sulfate.

The permit-required parameters were below their respective Ground Water Quality Rule (IDAPA 58.01.11) PCSs or SCSs during the 2017 reporting year for all six wells.

The filtered aluminum, iron, and manganese concentrations in all five wells were significantly lower than their respective SCS. Filtered aluminum, iron and manganese concentrations in the five monitoring wells were typically below the laboratory instrument minimum detection limits or just slightly above.

The sulfate and TDS concentrations in the groundwater wells continued to be monitored. USGS-065, downgradient of the CWP, tends to have elevated sulfate and TDS concentrations compared to the other monitoring wells, but these concentrations remain well below their applicable SCS of $250 \mathrm{mg} / \mathrm{L}$ and 500 $\mathrm{mg} / \mathrm{L}$, respectively. The highest sulfate concentration was $150 \mathrm{mg} / \mathrm{L}$ in the May 2017 sample and the 
highest TDS concentration was $417 \mathrm{mg} / \mathrm{L}$ in the September 2017 sample. The sulfate and TDS concentrations in the other five monitoring wells, including USGS-058, were significantly lower than those in USGS-065. The concentrations of sulfate and TDS from USGS-058, located slightly upgradient of the North Pond, were similar to concentrations in Middle-1823 which is located significantly downgradient from the CWP. A detailed trend analysis for sulfate and TDS is discussed in Section 6.

Although some of the reported concentrations may be considered questionable, inaccurate, or imprecise, the estimated values are provided in Table 3. These qualified data are discussed below:

- The May 2017 TKN result for USGS-098, USGS-065, TRA-08, Middle-1823 was U qualified due to blank contamination.

- The September 2017 TKN result for USGS-065, TRA-08, and Middle-1823 (duplicate) was $\mathrm{U}$ qualified due to blank contamination. A $U$ qualification during data validation indicates the analyte was detected at or above the applicable detection limit but the value was not more than 5 times the highest positive amount in any laboratory blank.

- The September 2017 chloride result for USGS-065 was J qualified due to high initial calibration bias.

- The May 2017 manganese result for TRA-08 and Middle-1823 was J qualified due to a potential false positive.

\subsection{Water Table Information}

Depth to water and water table elevations for the May and September, 2017 sampling events are shown in Figure 4 and Figure 5, respectively. The elevations are presented in North American Vertical Datum of 1988 (NAVD 88). In addition, the figures show the inferred general groundwater flow direction in the vicinity of the ATR Complex. In this area, the flow is in a south to southwest direction. The general groundwater flow direction at the INL Site is to the southwest. 
Table 3. Advanced Test Reactor Complex Cold Waste Ponds aquifer monitoring well data for the 2017 reporting year.

\begin{tabular}{|c|c|c|c|c|c|c|c|c|c|c|c|c|c|}
\hline \multirow{2}{*}{$\begin{array}{l}\text { WELL NAME } \\
\text { Sample Date }\end{array}$} & \multicolumn{2}{|c|}{$\begin{array}{l}\text { USGS-098 } \\
(\text { GW-16101) }\end{array}$} & \multicolumn{2}{|c|}{$\begin{array}{l}\text { USGS-065 } \\
\text { (GW-16102) }\end{array}$} & \multicolumn{2}{|c|}{$\begin{array}{l}\text { USGS-076 } \\
\text { (GW-16104) }\end{array}$} & \multicolumn{2}{|c|}{$\begin{array}{c}\text { TRA-08 } \\
(\mathrm{GW}-16105)\end{array}$} & \multicolumn{2}{|c|}{$\begin{array}{l}\text { Middle-1823 } \\
(\text { GW-16106) }\end{array}$} & \multicolumn{2}{|c|}{$\begin{array}{l}\text { USGS-058 } \\
\text { (GW-16107) }\end{array}$} & \multirow[t]{2}{*}{ PCS/SCS ${ }^{\mathbf{a}}$} \\
\hline & $05 / 4 / 17$ & 09/12/17 & 05/09/17 & 09/13/17 & 05/08/17 & 09/13/17 & 05/08/17 & 09/13/17 & 05/04/17 & 09/12/17 & $05 / 04 / 17$ & 09/14/17 & \\
\hline $\begin{array}{c}\text { Water Table Depth } \\
\text { (ft below ground surface) }\end{array}$ & 429.36 & 429.64 & 476.97 & 476.74 & 484.95 & 484.67 & 490.18 & 489.84 & 494.56 & 494.56 & 472.93 & 472.66 & $\mathrm{NA}^{\mathrm{b}}$ \\
\hline 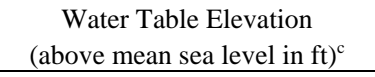 & 4459.85 & 4459.57 & 4451.60 & 4451.83 & 4448.26 & 4448.54 & 4448.88 & 4449.22 & 4448.31 & 4448.31 & 4448.96 & 4449.23 & NA \\
\hline Borehole Correction Factor $(\mathrm{ft})^{\mathrm{d}}$ & 2.53 & 2.53 & NA & NA & NA & NA & 0.63 & 0.63 & NA & NA & NA & NA & NA \\
\hline $\begin{array}{c}\text { Nitrite + nitrate as nitrogen } \\
(\mathrm{mg} / \mathrm{L})\end{array}$ & 1.07 & 0.825 & 1.41 & 1.24 & 1.04 & 0.93 & 0.975 & 0.822 & 0.985 & $\begin{array}{c}0.855 \\
(0.865)^{\mathrm{e}} \\
\end{array}$ & $\mathrm{NR}^{\mathrm{f}}$ & NR & 10 (PCS) \\
\hline Total Kjeldahl nitrogen (mg/L) & $0.0398 \mathrm{U}^{\mathrm{g}}$ & $0.0325 \mathrm{U}$ & $0.132 \mathrm{U}$ & $0.0817 \mathrm{U}$ & $-0.0032 \mathrm{U}$ & $-0.00857 \mathrm{U}$ & $0.0362 \mathrm{U}$ & $0.0793 \mathrm{U}$ & $0.146 \mathrm{U}$ & $\begin{array}{l}-0.0097 \mathrm{U} \\
(0.314 \mathrm{U})\end{array}$ & NR & NR & NA \\
\hline Total nitrogen $^{\mathrm{h}}(\mathrm{mg} / \mathrm{L})$ & 1.11 & 0.86 & 1.54 & 1.32 & $<1.07$ & $<0.96$ & 1.01 & 0.90 & 1.13 & $\begin{array}{c}0.89 \\
(1.18) \\
\end{array}$ & NR & NR & NA \\
\hline pH (s.u.) & 7.24 & 6.75 & 7.59 & 7.20 & 7.90 & 6.83 & 7.84 & 7.26 & 7.61 & 7.09 & NR & NR & 6.5 to 8.5 (SCS) \\
\hline Electrical conductivity $(\mu \mathrm{S} / \mathrm{cm})$ & 393 & 386 & 567 & 553 & 419 & 380 & 417 & 388 & 404 & 420 & NR & NR & NA \\
\hline Chloride (mg/L) & 13.4 & 13.7 & 17.1 & $17.5 \mathrm{~J}^{\mathrm{i}}$ & 11.8 & 11.8 & 10.4 & 10.3 & 10.4 & $\begin{array}{c}10.3 \\
(10.4) \\
\end{array}$ & NR & NR & 250 (SCS) \\
\hline Sulfate (mg/L) & 21.5 & 21.6 & 150 & 143 & 34.8 & 34.3 & 44.5 & 43.7 & 34.3 & $\begin{array}{c}33.6 \\
(33.5) \\
\end{array}$ & 35.9 & 34.3 & 250 (SCS) \\
\hline Total dissolved solids (mg/L) & 221 & 196 & 394 & 417 & 243 & 267 & 231 & 280 & 243 & $\begin{array}{c}260 \\
(247) \\
\end{array}$ & 216 & 236 & 500 (SCS) \\
\hline Aluminum, filtered (mg/L) & $0.0193 \mathrm{U}$ & $0.0193 \mathrm{U}$ & $0.0193 \mathrm{U}$ & $0.0193 \mathrm{U}$ & $0.0193 \mathrm{U}$ & $0.0193 \mathrm{U}$ & 0.0953 & 0.0235 & $0.0193 \mathrm{U}$ & $\begin{array}{c}0.0193 \mathrm{U} \\
(0.0193 \mathrm{U}) \\
\end{array}$ & NR & NR & 0.2 (SCS) \\
\hline Chromium $^{j}$, total $(\mathrm{mg} / \mathrm{L})$ & 0.00752 & 0.00699 & 0.0852 & 0.0749 & 0.0119 & 0.0119 & 0.097 & 0.0202 & 0.0105 & $\begin{array}{c}0.0105 \\
(0.0101) \\
\end{array}$ & NR & NR & 0.1 (PCS) \\
\hline Chromium', filtered (mg/L) & 0.00677 & 0.00689 & 0.0112 & 0.00769 & 0.0115 & 0.0112 & 0.0209 & 0.0195 & 0.0108 & $\begin{array}{c}0.0102 \\
(0.0107) \\
\end{array}$ & NR & NR & 0.1 (PCS) \\
\hline Iron, filtered (mg/L) & $0.03 \mathrm{U}$ & $0.03 \mathrm{U}$ & $0.03 \mathrm{U}$ & $0.03 \mathrm{U}$ & $0.03 \mathrm{U}$ & $0.03 \mathrm{U}$ & 0.0324 & $0.03 \mathrm{U}$ & $0.03 \mathrm{U}$ & $\begin{array}{c}0.03 \mathrm{U} \\
(0.03 \mathrm{U}) \\
\end{array}$ & NR & NR & 0.3 (SCS) \\
\hline Manganese, filtered (mg/L) & $0.001 \mathrm{U}$ & $0.001 \mathrm{U}$ & $0.001 \mathrm{U}$ & $0.001 \mathrm{U}$ & $0.001 \mathrm{U}$ & $0.001 \mathrm{U}$ & $0.00124 \mathrm{~J}$ & $0.001 \mathrm{U}$ & $0.00167 \mathrm{~J}$ & $\begin{array}{c}0.00118 \\
(0.00115) \\
\end{array}$ & NR & NR & 0.05 (SCS) \\
\hline \multicolumn{14}{|c|}{ 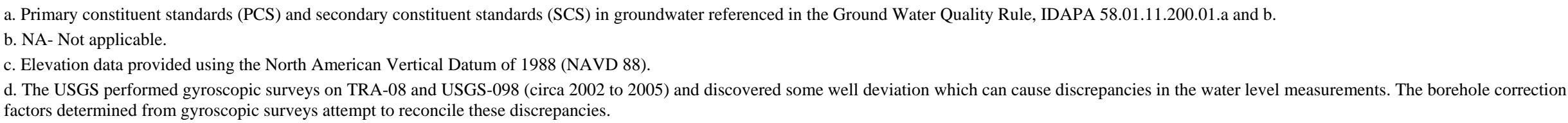 } \\
\hline \multicolumn{14}{|c|}{ e. Results shown in parenthesis are from the field duplicate samples. } \\
\hline \multicolumn{14}{|c|}{$\begin{array}{l}\text { f. NR indicates the parameter is not required by the Reuse Permit. } \\
\text { g. U qualification indicates the analyte was not detected above the instrument detection limit or the analyte was detected at or above the applicable detection limit but the value is not more than } 5 \text { times the highest } \\
\text { positive amount in any laboratory blank and is } U \text { qualified as a result of data validation. }\end{array}$} \\
\hline \multicolumn{14}{|c|}{$\begin{array}{l}\text { h. Total nitrogen is calculated as the sum of the total Kjeldahl nitrogen (TKN) and nitrite } \\
\text { for calculation purpose and the product was reported as a less than }(<\text { number. For positi } \\
\text { reported as a less than }(<) \text {. Results were rounded to the nearest hundredth. } \\
\text { i. J flag indicates the associated value is an estimate and may be inaccurate or imprecise. } \\
\text { j. PCS for Chromium does not apply under this permit. }\end{array}$} \\
\hline
\end{tabular}




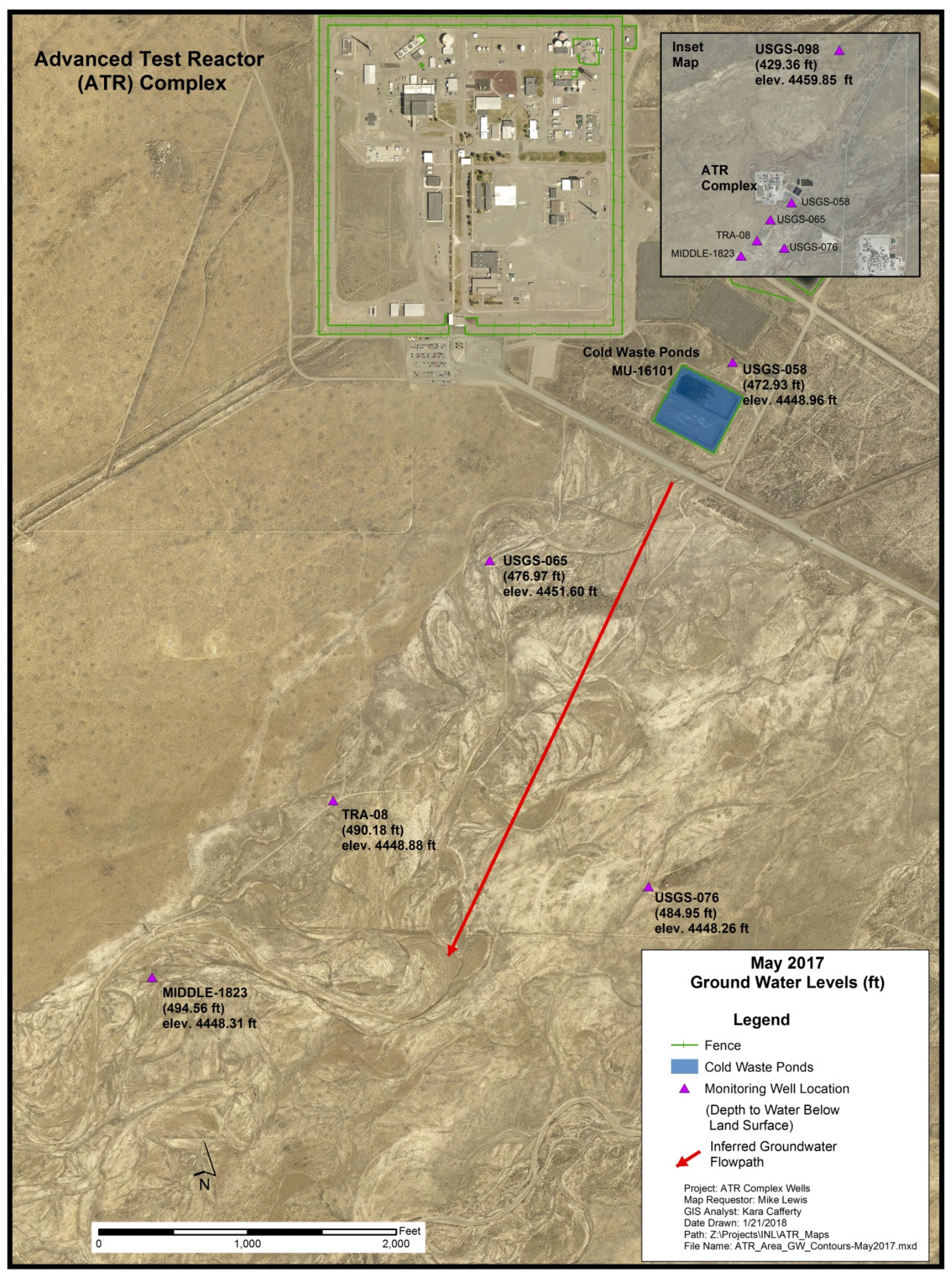

Figure 4. Map showing depths and elevations based on the May 2017 water level measurements. 


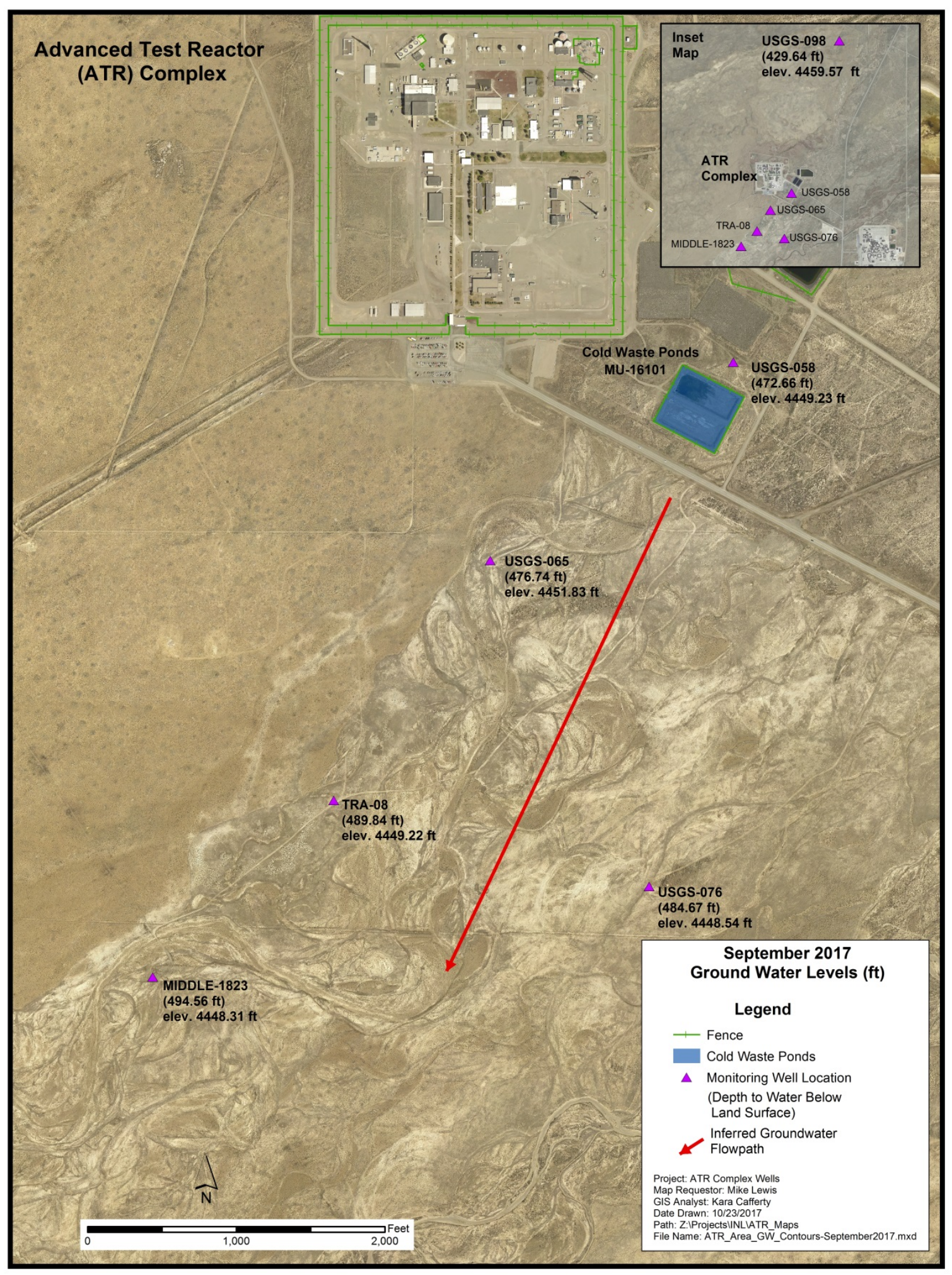

Figure 5. Map showing depths and elevations based on the September 2017 water level measurements. 


\section{PERMIT YEAR SUMMARIES}

This section provides information and status associated with permit required compliance activities and noncompliance issues.

\subsection{Status of Permit Required Compliance Activities}

Section 3 of the Reuse Permit identifies four compliance activities (CA-161-01 through 04) discussed below:

CA-161-01 - Within 12 months of permit issuance, the permittee shall submit for review and approval a Plan of Operation (PO) that reflects current operations and incorporates the requirements of the Reuse Permit. The PO shall be updated as needed to reflect current operations. The permittee shall notify DEQ of material changes to the PO and copies shall be kept on site and made available to DEQ upon request.

The PO was submitted to DEQ on November 19, 2015 (Miller 2015b). Approval of the PO from DEQ has not been received (John 2016).

CA-161-02 - Within 6 months of permit issuance, the permittee is required to prepare and implement a Quality Assurance Project Plan (QAPP) that incorporates all monitoring and reporting required by the permit. A copy of the QAPP and a written notice that the QAPP has been implemented shall be provided to DEQ.

A copy of the QAPP and the implementation notice were submitted to DEQ on May 18, 2015 (Miller 2015a).

CA-161-03 - Twelve months prior to permit expiration, the permittee shall contact DEQ and schedule a pre-application workshop to discuss the compliance status of the facility and the content required for the reuse permit application package.

This requirement has been added to the INL electronic Commitment Tracking System (CTS). This system provides automatic reminders to those responsible for completing the action. The permit expiration date is November 19, 2019; therefore, the first reminder date for this activity is May 18, 2018.

CA-161-04 - Six months prior to permit expiration the permittee shall submit to DEQ a complete permit renewal application package, which fulfills the requirements specified at the pre-application workshop identified in CA-161-03.

The first CTS reminder date for this activity is also May 18, 2018.

\subsection{Noncompliance/lssues}

There was one permit noncompliance for the 2017 reporting year. Condition 9.1.2 and IDAPA 58.01.01.16.600.2 requires application of wastewaters restricted to the premise of the application site.

\section{Noncompliance}

On July 25, 2017, a ball valve was discovered open westerly of TRA-671 (ATR Cooling Tower Pump House). Approximately 600 gallons of cooling water from ATR heat exchangers secondary cooling system (nonradioactive) was released to ground surface outside of the Reuse Permit, I-161-02, application site. The wastewater released contained corrosion inhibitors and biocide but did not endanger public health or the environment.

A courtesy conference call with DEQ was conducted on July 25, 2017 to discuss the release (Lewis 2017a). On July, 27, 2017, a five day written report was submitted as required by Section 8.500.06.d. of the permit. The report contained information specific to the release including description, cause, period of noncompliance and actions taken or planned to eliminate the occurrence. The report stated operations 
procedure OMM-7.4.13.1.6 "Draining the Secondary Coolant and UCW Systems" and two model work orders (MWO) 198794 and 198800 will be revised to include inspections of the ball valve to eliminate the recurrence of the noncompliance (Lewis 2017b).

A revised OMM-7.4.13.1.6 was released October 25, 2017 to include specific instructions concerning the operation of the isolation valve. The model work orders have also been revised, but remain in the planning phase until future need to clean the cooling tower basin.

\subsection{Department of Environmental Quality Annual Inspection}

The most recent inspection of the ATR Complex CWP by personnel from the DEQ Boise office occurred on October 12, 2016. DEQ found the ATR Complex CWP in substantial compliance with the Reuse Permit (John 2016).

Reuse facilities and structures visited during the inspection included monitoring well USGS-098, TRA-703 (Cold Waste Sump Pit), TRA-764 (Cold Waste Sampling Pit), and the CWP. Current operations were discussed including a planned future upgrade to the pump system, flow meter calibration date, dates and timing for switching flow to the ponds, monitoring activities, laboratory used for sample analysis, etc. DEQ reviewed laboratory and data validation reports.

DEQ provided two recommendations:

1. INL should contact the Idaho Falls Regional Office to discuss the interpretation of Item 8 in Section 6.1.2 of the Reuse Permit. This section requires "All laboratory analytical reports and chain of custody forms" are to be submitted in the annual report.

On March 7, 2017, DEQ issued Modification 1 to the INL ATR Complex Cold Waste Ponds. The permit modification updated Section 6.1.2, to read "Laboratory analytical result reports for monitoring specified in Section 5 of the permit. Chain of custody forms, supporting information for laboratory analytical reports, and quality assurance documentation shall be available for review upon request by DEQ" (Neher 2017).

2. "The facility should continue to update DEQ on the progress of the installation of a new control system for the pumps.”

On June 20, 2017, INL notified the Idaho Falls Regional Office (DEQ) of plans to upgrade control equipment (hereafter Upgrade Project) for TRA-703, a conveyance structure for the ATR Complex's cold waste collection system (Lewis 2017c). The notification reported that INL did not consider the upgrade to be a material modification and therefore did not require a DEQ review specified in IDAPA 58.01.17.500.06.a. On July 20, 2017, DEQ provided concurrence to the interpretation that INL did not need to submit plans and specifications for DEQ review and approval for the Upgrade Project (Rackow 2017).

On June 22, 2017, INL provided DEQ a thirty day notice of potential noncompliance due to the interruption of flowmeter service caused by the power outage necessary to install the control system upgrade for the Upgrade Pro (Miller 2017). Section 5.12 of the reuse permit requires daily flowmeter reading. As of the conclusion of the 2017 reporting year, the Upgrade Project is awaiting funding approval. Future status updates and any respective noncompliances will be provided in future annual reports.

\section{ENVIRONMENTAL IMPACTS}

The Reuse Permit allows 300 MG/year as a 5-year annual average, not to exceed 375 MG annually. The total volume discharged to the CWP for this period (November 1, 2016-October 31, 2017) was 234.05 MG. No runoff occurred from the application area. 
Total nitrogen concentrations in the effluent ranged between $<0.90 \mathrm{mg} / \mathrm{L}$ in the August 2017 sample to $4.87 \mathrm{mg} / \mathrm{L}$ in the June 2017 sample (Table 1). Nitrogen can be lost or removed from the soil by leaching, ammonia volatilization, and denitrification. Total nitrogen in the nearest downgradient well (USGS-065) from the CWP was less than $1.32 \mathrm{mg} / \mathrm{L}$ in the September 2017 sample and $1.54 \mathrm{mg} / \mathrm{L}$ in the May 2017 sample. The upgradient well (USGS-098) had total nitrogen (TN) concentrations of $0.86 \mathrm{mg} / \mathrm{L}$ and $1.11 \mathrm{mg} / \mathrm{L}$ for September 2017 and May 2017, respectively. The impact of TN on the groundwater from the CWP appears to be minimal.

Sulfate and TDS concentrations (Table 1) in the effluent have the potential to impact groundwater. Sulfate has high solubility and tends to move at a similar velocity as the groundwater (DEQ 2007). Sulfate and TDS sampling began in 2015 for USGS-098 and USGS-058. Sampling of USGS-098 and USGS-058 was not required by the previous permit.

Sulfate concentrations in the 2017 permit year effluent monthly samples ranged from a low of 20.2 $\mathrm{mg} / \mathrm{L}$ in the July 2017 sample to a high of $644 \mathrm{mg} / \mathrm{L}$ in the June 2017 sample. The TDS effluent concentrations ranged from a low of $223 \mathrm{mg} / \mathrm{L}$ in the July and September 2017 sample to a high of 1,220 mg/L in the June 2017 sample. There are no Reuse Permit effluent limits for sulfate and TDS. However, as discussed below, there are groundwater quality standards for these two parameters.

Figures 6 and 7 show the sulfate and TDS concentrations in samples collected from the Reuse Permit CWP monitoring wells. Sulfate and TDS data were not available for TRA-08 for October 2009 due to insufficient water available to collect a representative sample. Where a duplicate sample was collected, the original sample was used in generating the graphs.

USGS-065 has the highest sulfate concentrations of the six monitoring wells and it is the closest downgradient well to the CWP. As shown in Figure 6, the sulfate concentration in USGS-065 has remained below the SCS of $250 \mathrm{mg} / \mathrm{L}$.

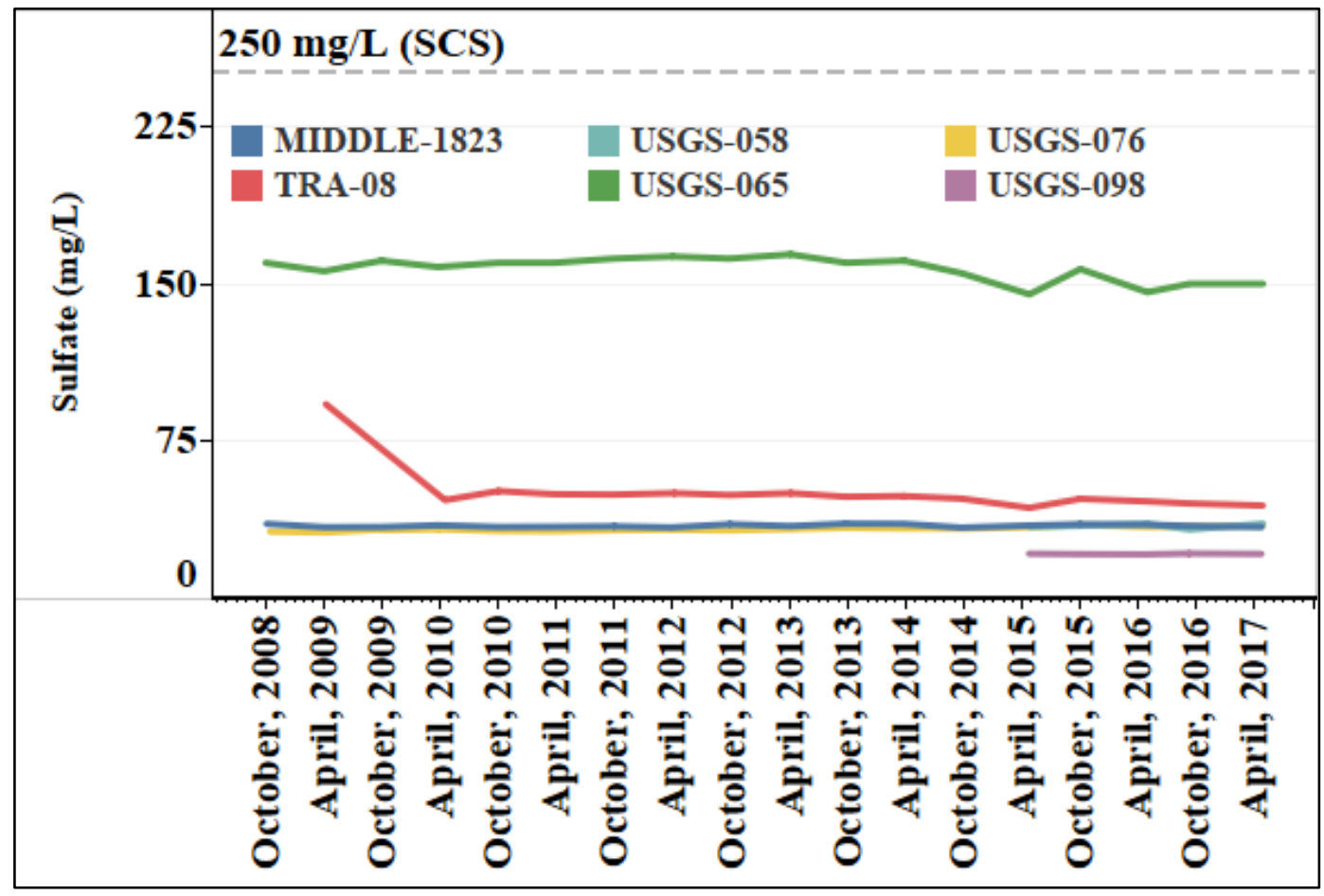

Figure 6. Sulfate concentrations in the Cold Waste Ponds monitoring wells. 
Similar to sulfate, the highest TDS concentration is in USGS-065 (Figure 7). The highest TDS concentration in USGS-065, for the reporting year, occurred in September 2017 at $417 \mathrm{mg} / \mathrm{L}$. The TDS concentration in USGS-065 has remained below the SCS of $500 \mathrm{mg} / \mathrm{L}$ (Figure 7).

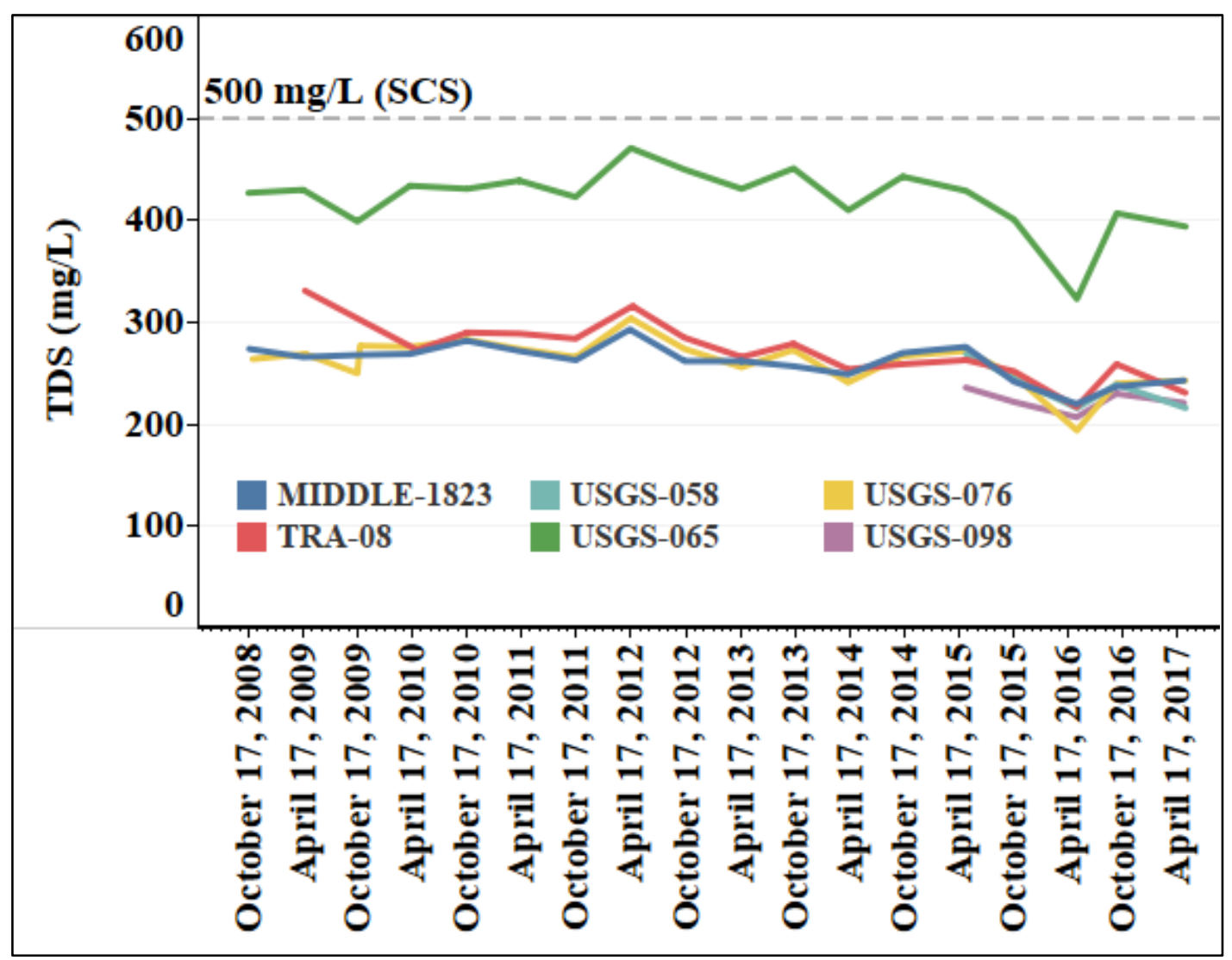

Figure 7. Total dissolved solids concentrations in the Cold Waste Ponds monitoring wells.

A Mann-Kendall trend analysis was performed on sulfate and TDS concentrations in the groundwater wells for the years 2013 to 2017. Sulfate concentrations were found to have no trend in USGS-058, and USGS-098, a decreasing trend in TRA-08, USGS-065, and Middle-1823, and an increasing trend in USGS-076 at the $90 \%$ confidence level (Table 4).

The concentrations of TDS were found to have no trend in USGS-076, TRA-08, Middle-1823, and USGS-058, and a decreasing trend in USGS-098 and USGS-065 at the 90\% confidence level (Table 5).

Table 4. Mann-Kendall trend analysis results for sulfate in the groundwater monitoring wells.

\begin{tabular}{|l|c|c|c|c|}
\hline Well Name & \# Samples & $\begin{array}{c}\text { Trend } \geq \mathbf{8 0 \%} \\
\text { Confidence }\end{array}$ & $\begin{array}{c}\text { Trend } \geq \mathbf{9 0 \%} \\
\text { Confidence }\end{array}$ & $\begin{array}{c}\text { Stability Check } \\
\text { (if no trend at } \mathbf{8 0} \% \\
\text { confidence) }\end{array}$ \\
\hline USGS-098 & 6 & No Trend & No Trend & Stable \\
\hline USGS-065 & 10 & Decreasing & Decreasing & NA $^{\text {a }}$ \\
\hline USGS-076 & 10 & Increasing & Increasing & NA \\
\hline TRA-08 & 10 & Decreasing & Decreasing & NA \\
\hline Middle-1823 & 10 & Decreasing & Decreasing & SA \\
\hline USGS-058 & 6 & No Trend & No Trend & \\
\hline a. Not applicable. & \multicolumn{4}{|l}{} \\
\hline
\end{tabular}


Table 5. Mann-Kendall trend analysis results for total dissolved solids in the groundwater monitoring wells.

\begin{tabular}{|l|c|c|c|c|}
\hline Well Name & \# Samples & $\begin{array}{c}\text { Trend } \geq \mathbf{8 0 \%} \\
\text { Confidence }\end{array}$ & $\begin{array}{c}\text { Trend } \geq \mathbf{9 0 \%} \\
\text { Confidence }\end{array}$ & $\begin{array}{c}\text { Stability Check } \\
\text { (if no trend at 80\% } \\
\text { confidence) }\end{array}$ \\
\hline USGS-098 & 6 & Decreasing & Decreasing & NA $^{\text {a }}$ \\
\hline USGS-065 & 10 & Decreasing & Decreasing & NA \\
\hline USGS-076 & 10 & No Trend & No Trend & Stable \\
\hline TRA-08 & 10 & No Trend & No Trend & Stable \\
\hline Middle-1823 & 10 & Decreasing & No Trend & NA \\
\hline USGS-058 & 6 & Decreasing & No Trend & \\
\hline a. Not applicable. &
\end{tabular}

With the exception of USGS-065, sulfate and TDS concentrations in the groundwater wells (Figures 6 and 7) are only slightly elevated when compared to the concentrations in background well USGS-098. The sulfate and TDS quickly dissipate with distance from the ponds. This can be seen when comparing the 2017 permit year sulfate and TDS concentrations found in USGS-065 and Middle-1823 (Figures 6 and 7). USGS-065 had a maximum sulfate concentration of $150 \mathrm{mg} / \mathrm{L}$ and a TDS concentration of 417 $\mathrm{mg} / \mathrm{L}$ for the 2017 report year located approximately 1,200 ft downgradient of the CWP. In contrast, Middle-1823, located approximately 4,000 ft downgradient from the CWP, had maximum sulfate and TDS concentrations of $34.3 \mathrm{mg} / \mathrm{L}$ and $260 \mathrm{mg} / \mathrm{L}$, respectively. The concentrations of sulfate and TDS in Middle-1823 are similar to the concentrations in the up/cross gradient well, USGS-076 (Figures 6 and 7).

As stated above, sulfate and TDS have SCSs for groundwater quality. The SCSs are generally based on aesthetic qualities including odor, taste, color, and foaming (EPA 1992). Sulfate is listed for causing a "salty taste" in drinking water. Total dissolved solids are listed for "hardness, deposits, colored water, staining, and salty taste." The nearest drinking water well is located approximately 3 miles downgradient of the CWP. Because the higher levels of sulfate and TDS are localized near the CWP and their SCSs are based on aesthetics, impacts to human health and the environment are expected to be minimal.

Groundwater concentrations for aluminum, chromium, iron, and manganese, in USGS-065, USGS076, TRA-08, and Middle-1823, were significantly lower than the applicable PCS or SCS (Table 3).

There are positive impacts to the environment associated with the operation of the CWP. These include returning a significant portion of the industrial wastewater to the aquifer and providing needed water for several native animal species in an otherwise semi-arid environment. 


\section{REFERENCES}

40 CFR 136, "Guidelines Establishing Test Procedures for the Analysis of Pollutants," Code of Federal Regulations, Office of the Federal Register, November 2017.

40 CFR 141, “National Primary Drinking Water Regulations," Code of Federal Regulations, Office of the Federal Register, November 2017.

40 CFR 143, “National Secondary Drinking Water Regulations," Code of Federal Regulations, Office of the Federal Register, March 2017.

DEQ, 2007, Guidance for Reclamation and Reuse of Municipal and Industrial Wastewater, Idaho Department of Environmental Quality, September 2007.

EPA, 1992, Secondary Drinking Water Regulations: Guidance for Nuisance Chemicals, EPA 810/K-92-001.

GDE-8511, “Inorganic Analyses Data Validation for INL,” Revision 0, January 25, 2007.

IDAPA 58.01.11, “Ground Water Quality Rule,” Idaho Department of Environmental Quality, March 2017.

John, A., DEQ, to T. A. Miller, INL, October 24, 2016, "I-161-02 INL ATR Cold Waste Ponds, 2016 Inspection,” CCN 239279.

John, A., DEQ, to T.A. Miller, INL, March 17, 2017, "I-161-02 Idaho National Laboratory (INL) Advanced Test Reactor (ATR) Complex Cold Waste Ponds, 2016 Annual Report Review,” CCN 240132.

Lewis, M. G., INL, to T. Rackow, DEQ, July 25, 2017a, "Minutes from June, 2017, Conference Call with DEQ Concerning ATR Complex Wastewater Release,” CCN 240894.

Lewis, M. G., INL, to T. Rackow, DEQ, July 27, 2017b, "Five Day Written Report Concerning the ATR Complex July 24-25, 2017, Wastewater Release,” CCN 240892.

Lewis, M. G., INL, to T. Rackow, DEQ, June 20, 2017c, "Installation Status of a New Control System for the ATR Complex Cold Waste System Pumps,” CCN 240641.

LI-330,'Groundwater Monitoring for the Advanced Test Reactor Complex Cold Waste Pond Industrial Wastewater Reuse Permit,” Revision 4. February, 27, 2017.

Miller, T. A., INL, to G. Eager, DEQ, May 18, 2015a, "Reuse Permit I-161-02 Compliance Activity CA161-02 Quality Assurance Project Plan Transmittal,” CCN 235805.

Miller, T. A., INL, to G. Eager, DEQ, November 19, 2015b, "Reuse Permit I-160-02 Compliance Activity CA-161-01 Plan of Operation Transmittal,” CCN 237051.

Miller, T. A., INL, to T. Rackow, DEQ, June 22, 2017, “Thirty-Day Notice for Reuse Permit t I-160-02Idaho National Laboratory Advanced Test Reactor Complex Cold Waste Ponds,” CCN 240632.

Neher, E., DEQ, to R. Boston, DOE-ID, November 20, 2014, “I-161-02 INL ATR Cold Waste Ponds, Final Permit," CCN 234522.

Neher, E., DEQ, to R. Boston, DOE-ID, March 7, 2017, "Idaho National Laboratory (INL) Advanced Test Reactor (ATR) Complex Cold Waste Ponds, Reuse Permit I-161-02, Modification 1,” CCN 240047.

Rackow, T., DEQ, to M. G. Lewis, INL, June 20, 2017, "DEQ Call Concerning the New Control System for the ATR Complex Cold Waste System Pumps,” CCN 240649. 


\section{Appendix A}

\section{Daily Discharge Volumes to the Advanced Test Reactor Complex Cold Waste Ponds}




\section{Appendix A}

\section{Daily Discharge Volumes to the Advanced Test Reactor Complex Cold Waste Ponds}

Table A-1. Daily discharge volumes to the ATR Complex CWP for the 2017 permit year.

\begin{tabular}{|c|c|c|c|c|c|}
\hline Date & $\begin{array}{l}\text { North Pond } \\
\text { (gal) }\end{array}$ & $\begin{array}{c}\text { South Pond } \\
\text { (gal) }\end{array}$ & Date & $\begin{array}{l}\text { North Pond } \\
\text { (gal) }\end{array}$ & $\begin{array}{c}\text { South Pond } \\
\text { (gal) }\end{array}$ \\
\hline $11 / 01 / 16$ & 293,520 & OOS & $12 / 15 / 16$ & OOS & 761,440 \\
\hline $11 / 02 / 16$ & 300,440 & OOS & $12 / 16 / 16$ & OOS & 691,600 \\
\hline $11 / 03 / 16$ & 289,370 & OOS & $12 / 17 / 16$ & OOS & 893,900 \\
\hline $11 / 04 / 16$ & 291,940 & OOS & $12 / 18 / 16$ & OOS & 525,460 \\
\hline $11 / 05 / 16$ & 282,250 & OOS & $12 / 19 / 16$ & OOS & 639,450 \\
\hline $11 / 06 / 16$ & 299,740 & OOS & $12 / 20 / 16$ & OOS & 303,880 \\
\hline $11 / 07 / 16$ & 284,760 & OOS & $12 / 21 / 16$ & OOS & 309,920 \\
\hline $11 / 08 / 16$ & 660,000 & OOS & $12 / 22 / 16$ & OOS & 388,020 \\
\hline $11 / 09 / 16$ & 760,380 & OOS & $12 / 23 / 16$ & OOS & 365,300 \\
\hline $11 / 10 / 16$ & 573,950 & OOS & $12 / 24 / 16$ & OOS & 452,100 \\
\hline $11 / 11 / 16$ & 639,670 & OOS & $12 / 25 / 16$ & OOS & 439,900 \\
\hline $11 / 12 / 16$ & 548,500 & OOS & $12 / 26 / 16$ & OOS & 396,300 \\
\hline $11 / 13 / 16$ & 679,900 & OOS & $12 / 27 / 16$ & OOS & 413,400 \\
\hline $11 / 14 / 16$ & 661,600 & OOS & $12 / 28 / 16$ & OOS & 444,080 \\
\hline $11 / 15 / 16$ & 698,230 & OOS & $12 / 29 / 16$ & OOS & 381,260 \\
\hline $11 / 16 / 16$ & 590,670 & OOS & $12 / 30 / 16$ & OOS & 362,600 \\
\hline $11 / 17 / 16$ & 710,900 & OOS & $12 / 31 / 16$ & OOS & 391,670 \\
\hline $11 / 18 / 16$ & 677,900 & OOS & $01 / 01 / 17$ & OOS & 392,950 \\
\hline $11 / 19 / 16$ & 597,500 & OOS & $01 / 02 / 17$ & 308,250 & OOS \\
\hline $11 / 20 / 16$ & 650,650 & OOS & $01 / 03 / 17$ & 312,620 & OOS \\
\hline $11 / 21 / 16$ & 644,910 & OOS & $01 / 04 / 17$ & 291,060 & OOS \\
\hline $11 / 22 / 16$ & 644,440 & OOS & $01 / 05 / 17$ & 326,810 & OOS \\
\hline $11 / 23 / 16$ & 737,340 & OOS & $01 / 06 / 17$ & 281,960 & OOS \\
\hline $11 / 24 / 16$ & 600,470 & OOS & $01 / 07 / 17$ & 313,300 & OOS \\
\hline $11 / 25 / 16$ & 663,190 & OOS & $01 / 08 / 17$ & 307,920 & OOS \\
\hline $11 / 26 / 16$ & 569,980 & OOS & $01 / 09 / 17$ & 364,060 & OOS \\
\hline $11 / 27 / 16$ & 686,760 & OOS & $01 / 10 / 17$ & 409,020 & OOS \\
\hline $11 / 28 / 16$ & 692,560 & OOS & $01 / 11 / 17$ & 366,950 & OOS \\
\hline $11 / 29 / 16$ & 662,510 & OOS & $01 / 12 / 17$ & 395,400 & OOS \\
\hline $11 / 30 / 16$ & 610,000 & OOS & $01 / 13 / 17$ & 400,900 & OOS \\
\hline $12 / 01 / 16$ & 757,620 & OOS & $01 / 14 / 17$ & 441,400 & OOS \\
\hline $12 / 02 / 16$ & OOS & 628,600 & $01 / 15 / 17$ & 376,150 & OOS \\
\hline $12 / 03 / 16$ & OOS & 616,200 & $01 / 16 / 17$ & 411,290 & OOS \\
\hline $12 / 04 / 16$ & OOS & 654,320 & $01 / 17 / 17$ & 412,970 & OOS \\
\hline $12 / 05 / 16$ & OOS & 644,050 & $01 / 18 / 17$ & 722,940 & OOS \\
\hline $12 / 06 / 16$ & OOS & 665,840 & $01 / 19 / 17$ & 778,650 & OOS \\
\hline $12 / 07 / 16$ & OOS & 722,580 & $01 / 20 / 17$ & 934,670 & OOS \\
\hline $12 / 08 / 16$ & OOS & 682,600 & $01 / 21 / 17$ & 681,090 & OOS \\
\hline $12 / 09 / 16$ & OOS & 593,300 & $01 / 22 / 17$ & 769,830 & OOS \\
\hline $12 / 10 / 16$ & OOS & 682,880 & $01 / 23 / 17$ & 537,820 & OOS \\
\hline $12 / 11 / 16$ & OOS & 646,580 & $01 / 24 / 17$ & 163,200 & OOS \\
\hline $12 / 12 / 16$ & OOS & 687,460 & $01 / 25 / 17$ & 289,150 & OOS \\
\hline $12 / 13 / 16$ & OOS & 645,960 & $01 / 26 / 17$ & 334,850 & OOS \\
\hline $12 / 14 / 16$ & OOS & 756,270 & $01 / 27 / 17$ & 294,290 & OOS \\
\hline
\end{tabular}




\begin{tabular}{|c|c|c|}
\hline Date & $\begin{array}{l}\text { North Pond } \\
\text { (gal) }\end{array}$ & $\begin{array}{c}\text { South Pond } \\
\text { (gal) }\end{array}$ \\
\hline $01 / 28 / 17$ & 318,200 & OOS \\
\hline $01 / 29 / 17$ & 309,060 & OOS \\
\hline $01 / 30 / 17$ & 359,990 & OOS \\
\hline $01 / 31 / 17$ & 396,880 & OOS \\
\hline $02 / 01 / 17$ & OOS & 380,500 \\
\hline $02 / 02 / 17$ & OOS & 399,000 \\
\hline $02 / 03 / 17$ & OOS & 404,710 \\
\hline $02 / 04 / 17$ & OOS & 336,950 \\
\hline $02 / 05 / 17$ & OOS & 378,120 \\
\hline $02 / 06 / 17$ & OOS & 394,570 \\
\hline $02 / 07 / 17$ & OOS & 365,430 \\
\hline $02 / 08 / 17$ & OOS & 404,590 \\
\hline $02 / 09 / 17$ & OOS & 417,840 \\
\hline $02 / 10 / 17$ & OOS & 377,320 \\
\hline $02 / 11 / 17$ & OOS & 370,790 \\
\hline $02 / 12 / 17$ & OOS & 376,400 \\
\hline $02 / 13 / 17$ & OOS & 339,460 \\
\hline $02 / 14 / 17$ & OOS & 281,940 \\
\hline $02 / 15 / 17$ & OOS & 307,520 \\
\hline $02 / 16 / 17$ & OOS & 310,630 \\
\hline $02 / 17 / 17$ & OOS & 291,600 \\
\hline $02 / 18 / 17$ & OOS & 312,300 \\
\hline $02 / 19 / 17$ & OOS & 316,430 \\
\hline $02 / 20 / 17$ & OOS & 404,400 \\
\hline $02 / 21 / 17$ & OOS & 433,530 \\
\hline $02 / 22 / 17$ & OOS & 350,590 \\
\hline $02 / 23 / 17$ & OOS & 712,050 \\
\hline $02 / 24 / 17$ & OOS & 848,350 \\
\hline $02 / 25 / 17$ & OOS & 670,690 \\
\hline $02 / 26 / 17$ & OOS & 665,110 \\
\hline $02 / 27 / 17$ & OOS & 724,560 \\
\hline $02 / 28 / 17$ & OOS & 696,480 \\
\hline $03 / 01 / 17$ & 751,170 & OOS \\
\hline $03 / 02 / 17$ & 668,470 & OOS \\
\hline $03 / 03 / 17$ & 639,420 & OOS \\
\hline $03 / 04 / 17$ & 693,400 & OOS \\
\hline $03 / 05 / 17$ & 845,350 & OOS \\
\hline $03 / 06 / 17$ & 696,360 & OOS \\
\hline 03/07/17 & 670,850 & OOS \\
\hline $03 / 08 / 17$ & 680,700 & OOS \\
\hline $03 / 09 / 17$ & 809,500 & OOS \\
\hline 03/10/17 & 690,100 & OOS \\
\hline 03/11/17 & 864,700 & OOS \\
\hline 03/12/17 & 760,820 & OOS \\
\hline $03 / 13 / 17$ & 711,340 & OOS \\
\hline $03 / 14 / 17$ & 807,130 & OOS \\
\hline 03/15/17 & 824,680 & OOS \\
\hline 03/16/17 & 737,300 & OOS \\
\hline $03 / 17 / 17$ & 724,070 & OOS \\
\hline 03/18/17 & 919,000 & OOS \\
\hline 03/19/17 & 679,650 & oOs \\
\hline $03 / 20 / 17$ & 747,580 & OOS \\
\hline
\end{tabular}

\begin{tabular}{|c|c|c|}
\hline Date & $\begin{array}{l}\text { North Pond } \\
\text { (gal) }\end{array}$ & $\begin{array}{l}\text { South Pond } \\
\text { (gal) }\end{array}$ \\
\hline $03 / 21 / 17$ & 730,340 & OOS \\
\hline $03 / 22 / 17$ & 652,080 & OOS \\
\hline $03 / 23 / 17$ & 739,950 & OOS \\
\hline $03 / 24 / 17$ & 739,130 & OOS \\
\hline $03 / 25 / 17$ & 697,850 & OOS \\
\hline $03 / 26 / 17$ & 759,290 & OOS \\
\hline $03 / 27 / 17$ & 670,520 & OOS \\
\hline $03 / 28 / 17$ & 811,480 & OOS \\
\hline $03 / 29 / 17$ & 744,600 & OOS \\
\hline $03 / 30 / 17$ & 868,400 & OOS \\
\hline $03 / 31 / 17$ & 902,960 & OOS \\
\hline $04 / 01 / 17$ & 579,920 & OOS \\
\hline $04 / 02 / 17$ & 823,360 & OOS \\
\hline $04 / 03 / 17$ & OOS & 820,170 \\
\hline $04 / 04 / 17$ & OOS & 782,090 \\
\hline $04 / 05 / 17$ & OOS & 808,050 \\
\hline $04 / 06 / 17$ & OOS & 915,680 \\
\hline $04 / 07 / 17$ & OOS & 630,040 \\
\hline $04 / 08 / 17$ & OOS & 884,340 \\
\hline $04 / 09 / 17$ & OOS & 766,080 \\
\hline $04 / 10 / 17$ & OOS & 646,980 \\
\hline $04 / 11 / 17$ & OOS & 794,670 \\
\hline $04 / 12 / 17$ & OOS & 695,880 \\
\hline $04 / 13 / 17$ & OOS & 797,010 \\
\hline $04 / 14 / 17$ & OOS & 651,000 \\
\hline $04 / 15 / 17$ & OOS & 659,500 \\
\hline $04 / 16 / 17$ & OOS & 688,480 \\
\hline $04 / 17 / 17$ & OOS & 684,670 \\
\hline $04 / 18 / 17$ & OOS & 738,490 \\
\hline $04 / 19 / 17$ & OOS & 867,360 \\
\hline $04 / 20 / 17$ & OOS & 767,860 \\
\hline $04 / 21 / 17$ & OOS & 711,860 \\
\hline $04 / 22 / 17$ & OOS & 911,500 \\
\hline $04 / 23 / 17$ & OOS & 709,320 \\
\hline $04 / 24 / 17$ & OOS & 732,610 \\
\hline $04 / 25 / 17$ & OOS & 830,950 \\
\hline $04 / 26 / 17$ & OOS & 804,480 \\
\hline $04 / 27 / 17$ & OOS & 820,140 \\
\hline $04 / 28 / 17$ & OOS & 830,000 \\
\hline $04 / 29 / 17$ & OOS & 790,000 \\
\hline 04/30/17 & OOS & 724,110 \\
\hline $05 / 01 / 17$ & 811,170 & OOS \\
\hline $05 / 02 / 17$ & 794,000 & OOS \\
\hline $05 / 03 / 17$ & 737,600 & OOS \\
\hline $05 / 04 / 17$ & 918,000 & OOS \\
\hline $05 / 05 / 17$ & 758,450 & OOS \\
\hline 05/06/17 & 832,200 & OOS \\
\hline $05 / 07 / 17$ & 714,900 & OOS \\
\hline 05/08/17 & 816,830 & OOS \\
\hline 05/09/17 & 762,260 & OOS \\
\hline 05/10/17 & 840,840 & OOS \\
\hline $05 / 11 / 17$ & 749,490 & OOS \\
\hline
\end{tabular}




\begin{tabular}{|c|c|c|}
\hline Date & $\begin{array}{l}\text { North Pond } \\
\text { (gal) }\end{array}$ & $\begin{array}{l}\text { South Pond } \\
\text { (gal) }\end{array}$ \\
\hline $05 / 12 / 17$ & 806,130 & OOS \\
\hline $05 / 13 / 17$ & 849,470 & OOS \\
\hline $05 / 14 / 17$ & 673,030 & OOS \\
\hline $05 / 15 / 17$ & 720,350 & OOS \\
\hline $05 / 16 / 17$ & 665,360 & OOS \\
\hline $05 / 17 / 17$ & 731,220 & OOS \\
\hline $05 / 18 / 17$ & 719,370 & OOS \\
\hline $05 / 19 / 17$ & 753,910 & OOS \\
\hline $05 / 20 / 17$ & 807,860 & OOS \\
\hline $05 / 21 / 17$ & 674,690 & OOS \\
\hline $05 / 22 / 17$ & 781,840 & OOS \\
\hline $05 / 23 / 17$ & 809,310 & OOS \\
\hline $05 / 24 / 17$ & 755,590 & OOS \\
\hline $05 / 25 / 17$ & 863,200 & OOS \\
\hline $05 / 26 / 17$ & 766,510 & OOS \\
\hline $05 / 27 / 17$ & 758,180 & OOS \\
\hline $05 / 28 / 17$ & 810,010 & OOS \\
\hline $05 / 29 / 17$ & 354,810 & OOS \\
\hline $05 / 30 / 17$ & 257,000 & OOS \\
\hline $05 / 31 / 17$ & 251,870 & OOS \\
\hline $06 / 01 / 17$ & OOS & 333,180 \\
\hline $06 / 02 / 17$ & OOS & 398,630 \\
\hline $06 / 03 / 17$ & OOS & 288,270 \\
\hline $06 / 04 / 17$ & OOS & 371,140 \\
\hline $06 / 05 / 17$ & OOS & 465,390 \\
\hline $06 / 06 / 17$ & OOS & 406,790 \\
\hline $06 / 07 / 17$ & OOS & 472,130 \\
\hline $06 / 08 / 17$ & OOS & 445,600 \\
\hline $06 / 09 / 17$ & OOS & 500,100 \\
\hline $06 / 10 / 17$ & OOS & 416,900 \\
\hline $06 / 11 / 17$ & OOS & 712,770 \\
\hline $06 / 12 / 17$ & OOS & 836,150 \\
\hline $06 / 13 / 17$ & OOS & 868,370 \\
\hline $06 / 14 / 17$ & OOS & 845,330 \\
\hline $06 / 15 / 17$ & OOS & 856,130 \\
\hline $06 / 16 / 17$ & OOS & 834,710 \\
\hline $06 / 17 / 17$ & OOS & 760,050 \\
\hline $06 / 18 / 17$ & OOS & 908,080 \\
\hline $06 / 19 / 17$ & OOS & $1,166,500$ \\
\hline $06 / 20 / 17$ & OOS & 723,000 \\
\hline $06 / 21 / 17$ & OOS & 714,500 \\
\hline $06 / 22 / 17$ & OOS & 722,530 \\
\hline $06 / 23 / 17$ & OOS & 795,190 \\
\hline $06 / 24 / 17$ & OOS & 544,780 \\
\hline $06 / 25 / 17$ & OOS & 759,950 \\
\hline $06 / 26 / 17$ & OOS & 903,360 \\
\hline $06 / 27 / 17$ & OOS & 779,420 \\
\hline $06 / 28 / 17$ & OOS & 841,570 \\
\hline $06 / 29 / 17$ & OOS & 763,300 \\
\hline $06 / 30 / 17$ & OOS & 842,860 \\
\hline $07 / 01 / 17$ & OOS & 897,100 \\
\hline $07 / 02 / 17$ & 810,420 & OOS \\
\hline
\end{tabular}

\begin{tabular}{|c|c|c|}
\hline Date & $\begin{array}{l}\text { North Pond } \\
\text { (gal) }\end{array}$ & $\begin{array}{c}\text { South Pond } \\
\text { (gal) }\end{array}$ \\
\hline $07 / 03 / 17$ & 771,310 & OOS \\
\hline $07 / 04 / 17$ & 802,900 & OOS \\
\hline $07 / 05 / 17$ & 997,810 & OOS \\
\hline $07 / 06 / 17$ & 705,080 & OOS \\
\hline $07 / 07 / 17$ & 880,350 & OOS \\
\hline $07 / 08 / 17$ & 803,620 & OOS \\
\hline $07 / 09 / 17$ & 826,230 & OOS \\
\hline $07 / 10 / 17$ & 832,360 & OOS \\
\hline $07 / 11 / 17$ & 735,410 & OOS \\
\hline $07 / 12 / 17$ & 803,950 & OOS \\
\hline $07 / 13 / 17$ & 901,300 & OOS \\
\hline $07 / 14 / 17$ & 826,490 & OOS \\
\hline $07 / 15 / 17$ & 839,000 & OOS \\
\hline $07 / 16 / 17$ & 746,520 & OOS \\
\hline $07 / 17 / 17$ & 674,080 & OOS \\
\hline $07 / 18 / 17$ & 757,110 & OOS \\
\hline $07 / 19 / 17$ & 647,800 & OOS \\
\hline $07 / 20 / 17$ & 682,700 & OOS \\
\hline $07 / 21 / 17$ & 750,810 & OOS \\
\hline $07 / 22 / 17$ & 689,700 & OOS \\
\hline $07 / 23 / 17$ & 659,320 & OOS \\
\hline $07 / 24 / 17$ & 890,520 & OOS \\
\hline $07 / 25 / 17$ & 778,110 & OOS \\
\hline $07 / 26 / 17$ & 866,280 & OOS \\
\hline $07 / 27 / 17$ & 887,240 & OOS \\
\hline $07 / 28 / 17$ & 769,860 & OOS \\
\hline $07 / 29 / 17$ & 769,430 & OOS \\
\hline $07 / 30 / 17$ & 858,880 & OOS \\
\hline $07 / 31 / 17$ & 838,140 & OOS \\
\hline $08 / 01 / 17$ & OOS & 704,590 \\
\hline $08 / 02 / 17$ & OOS & 751,720 \\
\hline $08 / 03 / 17$ & OOS & 846,270 \\
\hline $08 / 04 / 17$ & OOS & 661,900 \\
\hline $08 / 05 / 17$ & OOS & 670,800 \\
\hline $08 / 06 / 17$ & OOS & 811,850 \\
\hline $08 / 07 / 17$ & OOS & 817,980 \\
\hline $08 / 08 / 17$ & OOS & 670,300 \\
\hline $08 / 09 / 17$ & OOS & 795,690 \\
\hline $08 / 10 / 17$ & OOS & $1,104,270$ \\
\hline $08 / 11 / 17$ & OOS & 588,180 \\
\hline $08 / 12 / 17$ & OOS & 797,920 \\
\hline $08 / 13 / 17$ & OOS & 725,560 \\
\hline $08 / 14 / 17$ & OOS & 862,800 \\
\hline $08 / 15 / 17$ & OOS & 828,360 \\
\hline $08 / 16 / 17$ & OOS & 754,370 \\
\hline $08 / 17 / 17$ & OOS & 941,220 \\
\hline 08/18/17 & OOS & 771,100 \\
\hline $08 / 19 / 17$ & OOS & 834,170 \\
\hline $08 / 20 / 17$ & OOS & 840,650 \\
\hline $08 / 21 / 17$ & OOS & 707,210 \\
\hline $08 / 22 / 17$ & OOS & 732,190 \\
\hline $08 / 23 / 17$ & OOS & 730,610 \\
\hline
\end{tabular}




\begin{tabular}{|c|c|c|}
\hline Date & $\begin{array}{l}\text { North Pond } \\
\text { (gal) }\end{array}$ & $\begin{array}{l}\text { South Pond } \\
\text { (gal) }\end{array}$ \\
\hline $08 / 24 / 17$ & OOS & 650,790 \\
\hline $08 / 25 / 17$ & OOS & 799,300 \\
\hline $08 / 26 / 17$ & OOS & 590,400 \\
\hline $08 / 27 / 17$ & OOS & 782,100 \\
\hline $08 / 28 / 17$ & OOS & 803,910 \\
\hline $08 / 29 / 17$ & OOS & 846,090 \\
\hline $08 / 30 / 17$ & OOS & 826,800 \\
\hline $08 / 31 / 17$ & OOS & 847,270 \\
\hline $09 / 01 / 17$ & OOS & 837,840 \\
\hline $09 / 02 / 17$ & OOS & 973,820 \\
\hline $09 / 03 / 17$ & OOS & 683,870 \\
\hline $09 / 04 / 17$ & OOS & 728,810 \\
\hline $09 / 05 / 17$ & 707,160 & OOS \\
\hline $09 / 06 / 17$ & 740,240 & OOS \\
\hline $09 / 07 / 17$ & 755,180 & OOS \\
\hline $09 / 08 / 17$ & 699,270 & OOS \\
\hline $09 / 09 / 17$ & 724,690 & OOS \\
\hline 09/10/17 & 722,360 & OOS \\
\hline $09 / 11 / 17$ & 944,500 & OOS \\
\hline $09 / 12 / 17$ & 548,100 & OOS \\
\hline $09 / 13 / 17$ & 849,500 & OOS \\
\hline $09 / 14 / 17$ & 797,900 & OOS \\
\hline $09 / 15 / 17$ & 967,970 & OOS \\
\hline $09 / 16 / 17$ & 761,990 & OOS \\
\hline $09 / 17 / 17$ & 784,740 & OOS \\
\hline $09 / 18 / 17$ & 972,200 & OOS \\
\hline $09 / 19 / 17$ & 735,710 & OOS \\
\hline $09 / 20 / 17$ & 829,490 & OOS \\
\hline $09 / 21 / 17$ & 926,420 & OOS \\
\hline $09 / 22 / 17$ & 869,570 & OOS \\
\hline $09 / 23 / 17$ & 821,210 & OOS \\
\hline $09 / 24 / 17$ & 868,810 & OOS \\
\hline $09 / 25 / 17$ & 557,490 & OOS \\
\hline $09 / 26 / 17$ & 774,260 & OOS \\
\hline $09 / 27 / 17$ & 677,880 & OOS \\
\hline $09 / 28 / 17$ & 783,120 & OOS \\
\hline
\end{tabular}

\begin{tabular}{|c|c|c|}
\hline Date & $\begin{array}{l}\text { North Pond } \\
\text { (gal) }\end{array}$ & $\begin{array}{c}\text { South Pond } \\
\text { (gal) }\end{array}$ \\
\hline $09 / 29 / 17$ & 733,890 & OOS \\
\hline $09 / 30 / 17$ & 775,800 & OOS \\
\hline $10 / 01 / 17$ & OOS & 623,570 \\
\hline $10 / 02 / 17$ & OOS & 840,080 \\
\hline $10 / 03 / 17$ & OOS & 799,600 \\
\hline $10 / 04 / 17$ & OOS & 911,500 \\
\hline $10 / 05 / 17$ & OOS & 782,250 \\
\hline $10 / 06 / 17$ & OOS & 294,850 \\
\hline $10 / 07 / 17$ & OOS & 261,800 \\
\hline $10 / 08 / 17$ & OOS & 308,900 \\
\hline $10 / 09 / 17$ & OOS & 289,650 \\
\hline $10 / 10 / 17$ & OOS & 293,350 \\
\hline $10 / 11 / 17$ & OOS & 361,880 \\
\hline $10 / 12 / 17$ & OOS & 368,310 \\
\hline $10 / 13 / 17$ & OOS & 364,960 \\
\hline $10 / 14 / 17$ & OOS & 373,930 \\
\hline $10 / 15 / 17$ & OOS & 370,690 \\
\hline $10 / 16 / 17$ & OOS & 384,730 \\
\hline $10 / 17 / 17$ & OOS & 378,800 \\
\hline $10 / 18 / 17$ & OOS & 376,300 \\
\hline $10 / 19 / 17$ & OOS & 405,000 \\
\hline $10 / 20 / 17$ & OOS & 392,900 \\
\hline $10 / 21 / 17$ & OOS & 360,400 \\
\hline $10 / 22 / 17$ & OOS & 369,080 \\
\hline $10 / 23 / 17$ & OOS & 324,920 \\
\hline $10 / 24 / 17$ & OOS & 346,100 \\
\hline $10 / 25 / 17$ & OOS & 314,000 \\
\hline $10 / 26 / 17$ & OOS & 340,980 \\
\hline $10 / 27 / 17$ & OOS & 258,380 \\
\hline $10 / 28 / 17$ & OOS & 354,790 \\
\hline $10 / 29 / 17$ & OOS & 333,730 \\
\hline $10 / 30 / 17$ & OOS & 394,120 \\
\hline $10 / 31 / 17$ & OOS & 370,690 \\
\hline \multicolumn{3}{|c|}{$\begin{array}{l}\text { a. OOS indicates pond was out of service. The } \\
\text { respective pond is operable, but not receiving } \\
\text { effluent. }\end{array}$} \\
\hline
\end{tabular}

